\title{
Competency to Stand Trial in Federal Courts: Conceptual and Constitutional Problems
}

\author{
William T. Pizzi†
}

In 1898 Thomas Youtsey was indicted on federal charges of embezzling and willfully misapplying some $\$ 60,000$ as the cashier of the First National Bank of Newport, Kentucky.' Trial preparation was hampered by a series of severe epileptic attacks which impaired the defendant's memory to such an extent that he had trouble remembering even day-to-day events, let alone the transactions that were the basis of the indictment. Accordingly, counsel for Youtsey sought a continuance on the grounds that Youtsey's memory and judgment were impaired. In addition to offering the affidavits of three physicians who had examined the defendant, counsel was willing to have the defendant undergo any mental or physical exam that the court might find appropriate for determining whether the defendant should be tried. The court denied the motion for continuance, and the jury convicted Youtsey, rejecting defense arguments that Youtsey was not sane, or if sane, was so mentally impaired that he lacked the requisite mens rea for the crime charged. ${ }^{2}$

On appeal, the Sixth Circuit reversed Youtsey's conviction, holding that the trial court's denial of the defense counsel's pretrial motion was erroneous. ${ }^{3}$ The court noted that the defense motion, although nominally a motion for a continuance, was in reality aimed at preventing any trial due to the "present insanity" of the defendant. When the issue of "present insanity" is raised, the accused has the right to have that issue considered because "[i]t is not 'due process of law' to subject an insane person to trial upon an indictment involving liberty or life."4 In support of its opinion, the Sixth Circuit cited a number of common law authorities. According to Hale, an incapacitated defendant "ought not by law to be arraigned .... , but be remitted to prison until that incapacity be removed. The reason is because he cannot advisedly plead to the indictment."5 The court quoted Bishop's Criminal Procedure:

$\dagger$ Associate Professor of Law, University of Colorado.

1 United States v. Youtsey, 91 F. 864 (C.C.D. Ky. 1898).

2 Id. at $871-72,876,880$ (reporting in full the instructions of the trial court).

3 Youtsey v. United States, 97 F. 937 (6th Cir. 1899).

+ Id. at 941.

s Id. at 940 (quoting M. Hale, The History of the Pleas of the Crown 34 (1847)). 
An insane man cannot even plead to an indictment. Therefore, if, at the arraignment, counsel have reason to suppose their client too insane to take his trial, they should then make the objection, which, it is believed, can be adequately done orally to the court. Or the objection may proceed from a third person on affidavit, or the court may take it on its own observations. ${ }^{6}$

On the basis of these and other common law authorities the court concluded that "[i]t is fundamental that an insane person can neither plead to an arraignment, be subjected to trial, or, after trial, receive judgment, or, after judgment, undergo punishment."7

Although there was no federal statute specifying procedures for the disposition of the issue, the court held that the trial judge should have employed a method of his own choice in order to determine if the defendant was capable of defending himself. Personal inspection of the defendant by the trial judge and the use of an advisory jury were among the possible techniques suggested by earlier cases which the Sixth Circuit indicated were available to the trial court. ${ }^{8}$ In reversing the conviction, the court said that "some mode, in the discretion of the court, [should] be adopted for a thorough investigation of the sanity of the accused," before Youtsey could be retried.

Even though the procedures for determining competency are now mandatory in the federal courts and in most state jurisdictions, the Youtsey case illustrates many of the problems surrounding the issue of present insanity, or, as it is now commonly called, competency to stand trial. First, the fact pattern of Youtsey is fairly typical. While competency may be raised at any point in the progression of criminal proceedings, it is usually raised at or soon after arraignment, ${ }^{10}$ and is usually brought to the court's attention by defense counsel, who may have experienced some difficulty in communicating with his client."

Second, Youtsey illustrates the important distinction between

5 Id. at 942 (quoting $2 \mathrm{~J}$. Bishop, Criminal Procedure $\S 666$ (3d ed. 1880)).

7 Id. at 940 .

*Id. at 943 .

Id. at 947.

10 Judicial Conference of the District of Columbia Circuit, Report of the Committee on Problems Connected with Mental Examination of the Accused in Criminal Cases 24 (1965) [hereinafter cited as D.C. STUDY]. The D.C. Study is based in part on a review of the docket entries of all persons indicted in the United States District Court for the District of Columbia from July 1, 1951 through July $30,1963 . I d$. at 5 .

11 The D.C. Study found that from fiscal 1952 through fiscal 1963, 85.7\% of the motions that requested pretrial mental examination of the defendant were filed by the defense. Id. at 24. 
competency to stand trial and the insanity defense. The term "competency at the time of the offense" of a discussion of insanity, while the term "insanity at the time of trial"13 has been used to describe questions of competency, creating the impression that competency and the insanity defense are closely related. Although psychiatric experts are relied upon in determining questions of both competency and insanity, the issues involved are very different. In Youtsey both an insanity defense and a defense based on the defendant's incapacity to entertain the requisite mens rea were raised and subsequently rejected by the jury. But this determination did not resolve the issue of the defendant's competency to stand trial. Insanity is a trial defense concerned with the defendant's mental condition at the time of the crime. Competency, on the other hand, concerns the defendant's ability to interact with his attorney and to understand the proceedings he faces. The court in Youtsey suggested that an inquiry into competency should focus on "the mental capacity of the accused to understand the proceedings against him, and rationally advise with his counsel as to his defense." ${ }^{14}$ In Dusky $v$. United States, ${ }^{15}$ the Supreme Court expanded and clarified this definition. The test, said the Court, is whether the defendant "has sufficient present ability to consult with his lawyer with a reasonable degree of rational understanding -and whether he has a rational as well as factual understanding of the proceedings against him."16

In this article I shall examine the procedures for determining competency in federal courts and shall consider in order the manner of raising the issue, the psychiatric examination, and the competency hearing. I shall be concerned throughout this article with working out the implications of the competency issue for the defendant, the trial court, the government attorney, and, in particular, the defense attorney. I shall suggest that the present procedures raise serious constitutional problems and, in the final section, I shall discuss reform of the present procedures on competency-in partic-

12 See, e.g., United States v. Munz, 542 F.2d 1382, 1384 (10th Cir. 1976), cert. denied, 429 U.S. 1104 (1977); United States v. Maret, 433 F.2d 1064, 1066 (8th Cir. 1970).

${ }_{13}$ See, e.g., Lee v. Wiman, 280 F.2d 257, 264 (5th Cir. 1960); United States ex rel. Leon v. Banmiller, 179 F. Supp. 390, 392 (E.D. Pa. 1959).

14 $97 \mathrm{~F}$. at 944 .

15 362 U.S. 402 (1960) (per curiam).

16 Id. While the test in Dusky remains the standard test for competency, the Ninth Circuit has adopted a second test which is aimed at determining a defendant's competency to plead guilty. The position of the Ninth Circuit is discussed in note 46 infra. 
ular, the provision on competency now being considered by Congress as part of the Criminal Code Reform Act of $1977 .{ }^{17}$

\section{Raising the ISSUe of Competency}

In 1949 Congress first enacted legislation ${ }^{18}$ (now codified at sections 4244-48 of title 18 of the United States Code) that deals comprehensively with the problems presented by defendants (1) who are awaiting trial and might be incompetent (section 4244), (2) who are in prison pursuant to conviction and believed to have been incompetent at trial (section 4245), or (3) who have become insane and dangerous while in prison and whose sentences are about to expire (section 4247). James V. Bennett, ${ }^{19}$ then Director of the United States Prisons, and then Attorney General Tom C. Clark, ${ }^{20}$ among those urging passage of the bill, expressed concern over the number of prisoners who had been convicted and sent to federal prisons even though they probably were not competent to stand trial in the first place. ${ }^{21}$

Section 4244 concerns the determination of competency prior to trial. The statute requires the United States Attorney to file a motion for judicial determination of the accused's competency whenever he has "reasonable cause to believe" that the accused "may be presently insane or otherwise so mentally incompetent as to be unable to understand the proceedings against him or properly to assist in his own defense. . . ."22 Upon the government attorney's motion,

12 S. 1437 entitled "The Criminal Code Reform Act of 1977" was introduced into the Senate by Senators McClellan and Kennedy on May 2, 1977. 123 Cong. Rec. S6833 (daily ed. May 2, 1977). The bill was voted out of the Senate Judiciary Committee on November 2, 1977 by a vote of 14-2. 35 Cong. QTRLY. WeEkLY REPORT 2364 (Nov. 5, 1977).

is Actually the bill was introduced into the 80th Congress as S. 850 and hearings were held on it by a Subcommittee of the Senate Judiciary Committee. Hearings on S. 850 Before a Subcomm. of the Senate Comm. on the Judiciary, 80th Cong., 2d Sess. (1948) [hereinafter cited as Hearings]. Although the bill was reported out of the Judiciary Committee, it failed of further action and was reintroduced in the 81st Congress where it was enacted. CARE AND Custody of Insane Persons Charged with or Convicted of Offenses against the United States, S. ReP. No. 209, 81st Cong., 1st Sess. (1949).

19 Hearings, supra note 18, at 12-13 (testimony of James V. Bennett).

20 Care and Custody of Insane Federal Prisoners, S. Rep. No. 1511, 80th Cong., 2d Sess. 2 (1948) (letter of Tom C. Clark).

21 The bill, as passed, was similar to a proposal that had been drawn up by a subcommittee of senior circuit judges chaired by Judge Calvert Magruder; this judicial proposal was approved by the Judicial Conference of the United States. See REPORT OF THE JUdicial CoNference of Senior Circuit Judges, Annual Report of the Director of the Administrative OfFice of The United States Courts 27 (1947).

${ }_{22} 18$ U.S.C. $\$ 4244$ (1970). In 1955 Congress passed a competency statute dealing solely with the District of Columbia, 24 D.C. CoDE $\S 301$ (1973), which appears slightly narrower than section 4244. Section 301 (a) requires a showing of "prima facie" evidence of incompetency to raise the issue. But the statute has been liberally interpreted, see Mitchell v. United 
or a similar motion on behalf of the accused, or on its own motion, the court

shall cause the accused, whether or not previously admitted to bail, to be examined as to his mental condition by at least one qualified psychiatrist, who shall report to the court. For the purpose of the examination the court may order the accused committed for such reasonable period as the court may determine to a suitable hospital or other facility to be designated by the court. If the report of the psychiatrist indicates a state of present insanity or such mental incompetency in the accused, the court shall hold a hearing, upon due notice, at which evidence as to the mental condition of the accused may be submitted, including that of the reporting psychiatrist, and make a finding with respect thereto. ${ }^{23}$

Essentially section 4244 mandates psychiatric examination whenever competency is raised. If the psychiatric report indicates that the defendant may be incompetent, there must be a hearing on the question and the court must make a finding on the issue. If the court finds that the defendant is incompetent, section 4246 authorizes the court to commit the defendant to the custody of the Attorney General until the defendant regains competency or the charges are dismissed. ${ }^{24}$

\section{A. The Court}

The common law approach to problems of competency stressed the trial court's responsibility to recognize and respond to evidence suggesting that the defendant may not be competent to stand trial. Indeed, it has long been recognized that the trial court is empowered

States, 316 F.2d 354, 360 (D.C. Cir. 1963), and appears to have made little difference in the practice in the District. See D.C. STuDY, supra note 10, at 22-23. See also discussion at note 121 infra.

${ }^{23} 18$ U.S.C. $\S 4244$ (1970).

${ }^{24} 18$ U.S.C. $\$ 4246$ (1970). The procedural aspects of section 4246 of the 1949 bill were probably less important to trial courts and federal prosecutors than the fact that the bill called for suitable facilities for examining defendants and for holding defendants found incompetent. Judge Magruder testified before the Judiciary Subcommittee:

It is the power and duty of the judge to be assured the man is competent to stand trial, and the fact of the matter is in many cases I have been told, judges blink at the fact because the Government has, so to speak, the bear by the tail and does not know what to do with him if it does not try him and put him in jail, because there is not [sic] procedure by which a person who is charged with crime but who is incapable of being tried because of mental condition-there is no procedure by which such person could be held indefinitely even though he may be one who would be a menace to be left at large. Hearings, supra note 18 , at 5 . 
to raise the issue on its own motion. ${ }^{25}$

This special responsibility of the trial court has been reaffirmed by the Supreme Court in two recent cases. ${ }^{26}$ In Pate $v$. Robinson ${ }^{27}$ the Supreme Court reversed a murder conviction because evidence introduced at trial showed that the defendant had a long history of severe mental problems punctuated with violence to himself and others. The Supreme Court concluded that in the face of such evidence the trial court's failure to order an inquiry into Robinson's competence to stand trial violated Robinson's right to a fair trial.

In the most recent Supreme Court case on competency-Drope $v$. Missouri ${ }^{28}$ - the trial court failed to order an inquiry into the competency of the defendant despite the report during the trial that the defendant had attempted suicide by shooting himself. Other information questioning the defendant's competency had been brought to the court's attention prior to and during the trial, including testimony from the defendant's wife as to the defendant's bizarre behavior and need for psychiatric care. The Supreme Court held that the suicide attempt viewed in conjunction with the other information mandated suspension of the trial until an evaluation and hearing concerning the defendant's competence. The Court declared that "[e]ven when a defendant is competent at the commencement of his trial, a trial court must always be alert to circumstances suggesting a change that would render the accused unable to meet the standards of competence to stand trial." ${ }^{29}$

25 See 2 J. Bishop, Criminal Procedure $\S 666$ (3d ed. 1880). See also Rex v. Frith, 22 How. St. Tr. 307, 310 (1790), where the defendant was charged with treason, and counsel for the defendant sought a trial continuance which the defendant opposed. In the course of argument over the continuance, the court itself raised the issue of the defendant's competency with the following observation:

It is impossible for the most inattentive observer not to be aware that there may in this case be a previous inquiry necessary: such is the humanity of the law of England, that in all stages both when the act is committed, at the time when the prisoner makes his defence, and even at the day of execution, it is important to settle what his state of mind is; and at the time he is called to plead, if there are circumstances that suggest to one's mind that he is not in the possession of his reason, we must certainly be careful that nothing is introduced into the administration of justice, but what belongs to that administration. The justice of the law has provided a remedy in such cases; therefore I think there ought now to be an inquiry made, touching the sanity of this man at this time; whether he is in a situation of mind to say what his grounds of defence here are. I know it is untrodden ground though it is constitutional: then get a jury together to inquire into the present state of his mind; the twelve men that are here will do.

Id. at 311 (note omitted).

26 Drope v. Missouri, 420 U.S. 162 (1975); Pate v. Robinson, 383 U.S. 375 (1966).

27383 U.S. 375 (1966).

2* 420 U.S. 162 (1975).

29 Id. at 181. 
The Supreme Court's opinions in Robinson and Drope indicate that due process requires trial courts to raise competency sua sponte..$^{30}$ Although section 4244 does not expressly require courts to raise the issue of competency, federal courts have repeatedly held that due process imposes such an obligation on trial courts. ${ }^{31}$

\section{B. Defense Counsel}

For practical reasons, the key to the competency issue is the defense attorney. The defense attorney has the most exposure to his client, and, unlike the court or prosecutor, he witnesses his client's behavior on various occasions and in various settings and circumstances. Given the test for incompetency, the importance of the defense attorney is not surprising; he generally has the best opportunity to notice any defects in the defendant's "ability to consult with his lawyer." ${ }^{32}$ By contrast, the court's contacts with the defendant are fleeting and are usually limited to observations of the defendant in a formal courtroom setting, where the defendant's active participation is minimal and where a certain amount of confusion and nervousness on the part of the defendant is to be expected. Moreover, in many of the cases that go to trial, and particularly in those cases that result in a guilty plea, ${ }^{33}$ the court may not even hear direct testimony from the defendant. Thus, the defense attorney is usually in the best position to raise the question of competency.

But raising competency may result in consequences that are very undesirable for a defendant. Under section 4246 the court is authorized to commit an accused defendant found incompetent to the custody of the Attorney General "until the accused shall be mentally competent to stand trial or until the pending charges

30 In both Drope and Robinson, state statutes required the trial court to investigate the issue of competency sua sponte, whenever the evidence suggested reason to believe the defendant might be incompetent. Illinois at the time of Robinson's conviction required a hearing when the evidence before the court raised a "bona fide doubt" as to the defendant's competence. 1935 ILL. REv. STAT., ch. 38, $\$ \$ 592,593$ (repealed 1961). The Missouri statute requires a judge to order an examination when a judge or magistrate has "reasonable cause to believe" the defendant is incompetent. Mo. REv. STAT. $\$ 552.020(2)$ (1969). Both statutes are discussed in Drope, 420 U.S. at 172-73. The Court in Drope characterized Pate as holding "that the failure to observe procedures adequate to protect a defendant's right not to be tried or convicted while incompetent to stand trial deprives him of his due process right to a fair trial." 420 U.S. at 172.

"See, e.g., Durham v. Wyrick, 545 F.2d 41, 44 (8th Cir. 1976); United States v. DiGilio, 538 F.2d 972, 987 (3d Cir. 1976), cert. denied, 97 S. Ct. 733 (1977).

32 See text at note 16 supra.

${ }^{23}$ In fiscal year 1974, for example, $85 \%$ of the defendants convicted in federal courts entered pleas of guilty or nolo contendere. Administrative OfFice of THE UNITEd STATES Courts, Federal Offenders in United States District Courts 1972, Table H-1 (1975). 
against him are disposed of according to law." ${ }^{34}$ Under Jackson $v$. Indian $a^{35}$ the commitment of an incompetent defendant charged with a crime cannot exceed "a reasonable period of time necessary to determine whether there is a substantial probability that he will attain that capacity in the foreseeable future." ${ }^{36}$ If it is determined that there is no such probability, the state must institute civil commitment proceedings or release the defendant. Even if it is determined that the defendant will soon regain competency, his commitment can only be justified by a showing of continued progress. But even though permanent commitment is ruled out by Jackson and though section 4246 was never intended to allow indefinite commitment of the permanently incompetent, ${ }^{37}$ the temporary commitment under section 4246 may nevertheless amount to a year or more.$^{38}$ Furthermore, the determination of incompetency may lead to attempts to have the defendant civilly committed under state law. ${ }^{39}$ For a defendant facing minor charges, or a first time offender, a finding of incompetency may result in an involuntary hospitalization that substantially exceeds any sentence that might have resulted from his conviction, ${ }^{40}$ and, if he regains competency, he still

34 18 U.S.C. $\$ 4246$ (1970).

35406 U.S. 715 (1972).

38 Id. at 738.

37 See Hearings, supra note 18, at 7 (testimony of Judge Calvert Magruder). See generally Jackson v. Indiana, which notes a long line of federal cases indicating that the use of $\$ \S 4244$ and 4246 to provide a means of indefinite commitment is improper. 406 U.S. at 733.

3x In Drendel v. United States, 403 F.2d 55 (5th Cir. 1968) the Fifth Circuit took note of the policy at the Medical Center for Federal Prisoners in Springfield, Missouri, where many federal prisoners are sent when they are found incompetent. The Center's policy is to work with the defendant for up to eighteen months before making a determination of permanent incompetency.

The D.C. Study showed an erratic decline year by year in the average number of months that a defendant was hospitalized prior to regaining competency. From July 1,1952 , through June 30,1953 , the average was slightly over 26 months; from July 1, 1961 through June 30, 1962 , it was down to slightly under 11 months. D.C. STudy, supra note 10, at 160 .

A comprehensive four year study of competency by a team of psychiatrists and lawyers conducted in mental hospitals and state courts in Massachusetts found that with the exception of those defendants who are retarded, most incompetent defendants respond well to treatment and can be expected to regain a competent state within weeks or months of active treatment. The study was funded by the National Institute of Mental Health. LaBoratory of Community Psychiatry, Harvard Medical School, Competency to Stand Trial and MenTAL Illness 65 (DHEW Publ. No. (HSM) 73-9105 (1973)) [hereinafter cited as MassachusetTs Study].

39 Cf. United States v. Curry, 410 F.2d 1372 (4th Cir. 1969) ( $\$ 4248$ authorizes protective detention by the Attorney General or transfer to an institution of the state of defendant's residence if defendant is found to be dangerous).

10 In fiscal year 1974 over half of the defendants convicted in federal district courts were placed on probation or fined. Administrative OfFice of the UNITEd States Courts, Federal OfFenders in United States District Courts 1972, Table H-1 (1975). 
faces possible conviction and sentence on the outstanding criminal charges."1

The length of hospitalization is not the only possible adverse consequence of raising the competency issue. While a delay in trial may be expected to work to the disadvantage of the government in most cases, in certain cases a prompt trial may afford the accused his best chance for an acquittal. If the defendant intends to raise an affirmative defense or if the government is having problems locating a particular witness or certain evidence, any delay in trial may not be in the best interests of the defendant, particularly if he is ultimately found competent to stand trial.

Thus, the person with the best access to indicia of a defendant's incompetency-his attorney-may have strong incentives not to reveal his knowledge. Section 4244 does not impose a duty on defense counsel to raise the issue of competency. ${ }^{42}$ The consensus among commentators is that counsel should raise the issue only if it is in "the client's best interests." 43

This view is troubling. To leave disclosure to the discretion of defense counsel is, in effect, to assert that there is nothing improper in an attorney's proceeding to pleadings or trial with an incompetent criminal defendant. If counsel is free to decide that, despite his client's incompetency, it is in the client's best interest to proceed, the accused will be deprived of the right to participate intelligently in his own defense.

Consider the options facing counsel when he is confronted with a client whom he believes to be incompetent. Certainly a guilty plea may be an attractive alternative, for it is likely that the defendant's incompetency will increase the risk of surprise at trial and make a strong defense very difficult. But while it is counsel's function to present plea alternatives to his client and to make recommendations, the decision to plead belongs solely to the defendant and he

It should also be noted that with the exception of the District of Columbia, there are no commitment procedures for a defendant who raises a successful insanity defense in federal courts. United States v. McCracken, 488 F.2d 406, 416 (5th Cir. 1974). Section 3613 of S. 1437, the proposed revision of the federal criminal code, see note 17 supra, would change the present law by providing procedures for committing a defendant acquitted by reason of insanity.

"See Guy v. Ciccone, 439 F.2d 400, 401 (8th Cir. 1971). However, any sentence subsequently imposed should be reduced by the period of involuntary hospitalization.

12 The statute requires the court to order a psychiatric examination if a motion is made by anyone "in behalf of the accused." 18 U.S.C. $\$ 4244$ (1970). The language may suggest that the draftsmen assumed such motions would be brought by attorneys only when to do so served the client's best interests.

t3 See Eizenstat, Mental Competency to Stand Trial, 4 Harv. C.R.-C.L. REv. 379, 38384 (1969); Golten, Role of Defense Counsel in the Criminal Commitment Process, 10 AM. CrIm. L. Rev. 385, 389 (1972); Note, Incompetency to Stand Trial, 81 HaRv. L. REv. 454, 467 (1967). 
is, of course, free to see his interests differently from his attorney. As the Supreme Court has stated, it is the defendant who must "with the help of counsel, rationally weigh the advantages of going to trial against the advantages of pleading guilty." 44 If counsel allows his client to enter a plea that is not voluntary because the defendant is not competent, the attorney has failed in his primary obligation to ensure that the client's decision to plead is knowing and intelligent. ${ }^{45}$

The decision to enter a plea of not guilty and go to trial is really no different. A defendant who is unable to waive rights can hardly be said to be meaningfully asserting those rights. ${ }^{46}$ That counsel is present makes no difference for the decision to accept counsel is itself a matter of choice for a defendant. In Faretta v. California ${ }^{47}$ the Supreme Court held that a defendant in a state case has a right to self-representation under the sixth amendment and fourteenth amendment and that counsel cannot be forced on a defendant who voluntarily and intelligently elects to represent himself. The Court stated that:

The Sixth Amendment does not provide merely that a defense shall be made for the accused; it grants to the accused personally the right to make his defense. It is the accused, not counsel, who must be "informed of the nature and cause of the accusation," who must be "confronted with witnesses against him," and who must be accorded "compulsory process for obtaining witnesses in his favor." ...

It is true that when a defendant chooses to have a lawyer

" Brady v. United States, 397 U.S. 742, 750 (1970).

ts See McMann v. Richardson, 397 U.S. 759, $769-70$ (1970).

" One court has pointed out that procedural rights at trial have no value if the defendant is incompetent. Martin v. Estelle, 546 F.2d 177, 180 (5th Cir. 1977) (quoting Note, Incompetency to Stand Trial, 81 HARv. L. REv. 454, 457 (1967)). For this reason I think that the Ninth Circuit has made a mistake in deciding that the competency level required to stand trial is different from the competency required to plead guilty. In Sieling v. Eyman, 478 F.2d 211 (9th Cir. 1973) the court first indicated that competency to stand trial does not suffice to show competency to plead guilty. But see United States ex rel. McGough v. Hewitt, 528 F.2d 339,342 n.2 (3d Cir. 1975). The Ninth Circuit has required that in addition to the ability to understand and assist at his trial, the defendant who wishes to plead guilty must have the capacity to make a reasoned choice between standing trial and pleading guilty. Sailer $v$. Gunn, 548 F.2d 271, 275 (9th Cir. 1977).

This view ignores the fact that going to trial is itself a choice and trial will involve even further decisions. The danger of the dual standard is that it will weaken the standard of competency to stand trial. The ability to make reasoned choices should be viewed as part of the ability to understand the proceedings and assist counsel at trial. See Note, Competence to Plead Guilty: A New Standard, 1974 DukE L. J. 149.

17422 U.S. 806 (1975). 
manage and present his case, law and tradition may allocate to the counsel power to make binding decisions of trial strategy in many cases. . . . This allocation can only be justified, however, by the defendant's consent, at the outset, to accept counsel as his representative. ${ }^{48}$

The Court's decision reminds us that procedural guarantees are designed not only to ensure the reliability of fact-finding, but also to safeguard the defendant's dignity as an individual. ${ }^{49}$ The Court in Faretta conceded that its decision might result in some loss of reliability since most defendants would be better off with the assistance of counsel. Nevertheless, the Court concluded that "[p]ersonal liberties are not rooted in the law of averages," and the defendant's choice "must be honored out of "that respect for the individual which is the lifeblood of the law." "It has been suggested that the bar to the trial of an incompetent defendant is anachronistic in this day of appointed counsel, because counsel can ensure the fairness of the trial even if the defendant cannot..1 But even if counsel could guarantee a reliable trial, ${ }^{52}$ something important in the criminal process is lost when a defendant is convicted in a proceeding he does not understand and in which he cannot play even a minimal role. ${ }^{53}$

Ix Id. at 819-21.

" See generally Rochin v. California, 342 U.S. 165 (1952); Kadish, Methodology and Criteria in Due Process Adjudication-A Survey and Criticism; 66 YALE L. J. 319, 347 (1957).

so Faretta v. California, 422 U.S. 806, 834 (1975) (quoting Illinois v. Allen, 397 U.S. 337, 350-51 (1970) (Brennan, J., concurring)).

31 See Burt \& Morris, A Proposal for the Abolition of the Incompetency Plea, 40 U. CHI. L. Rev. 66, 75 (1972); Foote, A Comment on Pre-Trial Commitment of Criminal Defendants, 108 U. PA. L. Rev. 832, 844 (1960); Note, Incompetency to Stand Trial, 81 HARv. L. REv. 454, 467 (1967).

${ }^{32}$ In Faretta the Court suggested that much of the benefit of counsel may not be properly realized if the defendant does not want counsel. 422 U.S. at 832-35. That will certainly be equally true if the defendant is incompetent and cannot assist counsel. It may be that without help from the defendant many affirmative defenses will be foreclosed, particularly if the defendant is unable to testify.

${ }^{33}$ A nice compromise are those statutes which allow counsel to proceed with legal motions not requiring the personal participation of the defendant, e.g., N.Y. Crim. Proc. Law $\S$ 730.60(5) (McKinney 1971); MoNT. REv. CoDEs ANN. § 95-506(c) (1969), or those which allow "acquittal only" trials of particular defenses which cannot result in a guilty verdict. E.g., Mass. Ann. Laws ch. 123, \$17(b) (Michie/Law Co-op 1972). The Supreme Court in Jackson noted such statutes without disapproval. 406 U.S. at 740-41.

One proposal which I think is unacceptable is that put forward by Professors Burt and Morris, supra note 51. They would allow a defendant who cannot be restored to competency to be put on trial. There would be available some additional safeguards: (1) broader discovery; (2) a higher burden of proof from the government on the defense motion for a judgment of acquittal; and (3) the jury would be instructed that "in weighing the evidence against the defendant, it should take into account, in the defendant's favor, the disabilities under which 
Behind the question of counsel's role in raising the issue of competency lurk difficult questions concerning the control that a defense lawyer is entitled to exercise in conducting a criminal case. The proper extent of counsel's control over the various strategic decisions at trial has always been somewhat uncertain, particularly when those decisions affect the defendant's constitutional rights. ${ }^{54}$ There is support in the caselaw for the proposition that even when counsel is retained, it is ultimately for the defendant to decide whether to waive his presence at trial, ${ }^{55}$ whether to waive a jury trial, ${ }^{58}$ or whether to testify. ${ }^{57}$ Although Faretta pays lip service to

he went to trial." It seems very doubtful to me that these safeguards would provide an accurate determination of guilt in many cases. Their justification for allowing trial in such cases stems from their concern that many defendants who are permanently incompetent may be civilly committed and held indefinitely. But the answer seems to me to lie not in allowing incompetent defendants to be processed through the criminal system, but in reforms in the area of civil commitment.

${ }^{34}$ Many of the uncertainties in this area stem from attempts to apply language in Fay v. Noia, 372 U.S. 391 (1963), and Henry v. Mississippi, 379 U.S. 443 (1965). In Fay, the Supreme Court held that the failure to appeal a state conviction did not deprive the federal courts of the power to grant habeas corpus relief. The Court, however, cautioned that a "federal habeas judge may in his discretion deny relief to an applicant who has deliberately bypassed the orderly procedure of the state courts and in so doing has forfeited his state court remedies." 372 U.S. at 438 . The Court quoted Johnson v. Zerbst, 304 U.S. 458, 464 (1938), for the proposition that the deliberate bypass must constitute "an intentional relinquishment or abandonment of a known right or privilege" and stated that a decision "made by counsel not participated in by the petitioner does not automatically bar relief." 372 U.S. at 439 .

In Henry v. Mississippi, the defendant, charged with disturbing the peace, had been convicted because his attorney had failed to make a contemporaneous objection to the introduction of evidence seized in violation of the fourth amendment. The Court indicated that access to a federal forum could be barred if there was a deliberate bypass of a state procedural remedy. The Court remanded for a hearing on the bypass issue, stating that "trial strategy adopted by counsel without prior consultation with an accused will not, where the circumstances are exceptional, preclude the accused from asserting constitutional claims." 379 U.S. at 451 . The cases seem able to support almost any result depending on whether a court fastens on the "participation" language in Fay or the "exceptional circumstances" limitation in Henry. See generally Chused, Faretta and the Personal Defense: The Role of a Represented Defendant in Trial Tactics, 65 CALIF. L. Rev. 636, 639-41 (1977).

${ }^{35}$ Cross v. United States, 325 F.2d 626 (D.C. Cir. 1963). This is precisely the problem with proceeding with an incompetent defendant-the defendant is only present physically. See Foote, supra note 51 , at 834.

s6 Patton v. United States, 281 U.S. 276, 312 (1930), has often been cited for its strong language warning the trial courts of the duty to make inquiry of the defendant before accepting a waiver:

Not only must the right of the accused to a trial by a constitutional jury be jealously preserved, but the maintenance of the jury as a fact finding body in criminal cases is of such importance and has such a place in our traditions, that, before any waiver can become effective, the consent of government counsel and the sanction of the court must be had, in addition to the express and intelligent consent of the defendant. And the duty of the trial court in that regard is not to be discharged as a mere matter of rote, but with sound and advised discretion. . . .

Rule 23(a) of the Federal Rules of Criminal Procedure requires a written waiver of a jury trial 
the traditional system of allocating to counsel the power to make decisions of "trial strategy," 58 the thrust of the opinion is to reopen the question of this traditional allocation. If a defendant has the right to present his own defense, surely he should not be forced to

by the defendant and it has even been suggested that, in addition to the signing of the waiver form, trial judges would be well advised to question the defendant directly. See United States v. David, 511 F.2d 355, 360-61 (D.C.Cir. 1975); Estrada v. United States, 457 F.2d 255 (7th Cir.), cert. denied, 409 U.S. 858 (1972).

Of course the waiver of a jury trial should also be part of the court's inquiry in accepting a guilty plea from a defendant. See Boykin v. Alabama, 395 U.S. 238, 243-44 (1969).

s7 In a footnote in Faretta the Court stated:

This Court has often recognized the constitutional stature of rights that, though not literally expressed in the document, are essential to due process of law in a fair adversary process. It is now accepted, for example, that an accused has a right . . . to testify on his own behalf, see Harris v. New York, 401 U.S. 222, 225; Brooks v. Tennessee,. 406 U.S. $605,612 \ldots$

422 U.S. at 819 n.15.

The Court's footnote attempts to put to rest the uncertainty in federal courts over the source and nature of the right to testify. Compare this footnote in Faretta with United States v. Ives, 504 F.2d 935, 939-40 (9th Cir. 1974), vacated on other grounds, 421 U.S. 944 (1975), and United States v. Bentvena, 319 F.2d 916 (2d Cir.), cert. denied, 375 U.S 940 (1963).

In United States ex rel. Wilcox v. Johnson, 555 F.2d 115 (3d Cir. 1977), the question of control over the right to testify arose in a Pennsylvania rape case where the defendant Wilcox wished to testify over his counsel's objection that his testimony would undercut the consent defense she intended to raise. The court informed Wilcox that if he testified, the court would permit defense counsel to withdraw. On a petition for a writ of habeas corpus the District Court granted the writ, concluding that Wilcox had a constitutional right to testify under the due process clause which only he could waive and that the trial court's ruling impinged upon that right by forcing the defendant to decide whether to give up his right to counsel. On appeal, the Third Circuit carefully reviewed the case law in the area, concluding that the District Court's pronouncement of a defendant's constitutional right to testify "fairly reflects the recognition of such a right by the federal courts." Id. at 119. But the court went on to note that there was a statutory right to testify under Pennsylvania law and based its decision on the state right, ruling that it was improper for the court to condition the right to counsel on waiver of the state right to testify. Id. at 120-21.

As Wilcox demonstrates, once it is admitted that the defendant has a right to testify despite the wishes of counsel, it gives the defendant great control over the defense to be presented, for certainly counsel cannot put on a defense that is inconsistent with the defendant's testimony.

For another type of decision out of which a dispute over control could develop, see United States v. Bridgeman, 523 F.2d 1099, 1118-19 (D.C. Cir. 1975), cert. denied, 425 U.S. 961 (1976) (dispute between counsel and the defendant over the witnesses to be called at trial).

st 422 U.S. at 832-35. As indicated, the traditional allocation is not clear. The $A B A$ Standards for the Defense Function provide that the decisions cver which plea to enter, whether to waive a jury and whether to testify are to be made by the accused after full consultation with counsel. ABA Standards Relating to tHe Administration of Criminal Justice, The Defense Function $\$$ 5.2(a) (1971). Decisions over what witnesses to call, whether and how to conduct cross-examinations, what jurors to accept or strike, what trial motions should be made, and "all other strategic and tactical decisions" are "the exclusive province of the lawyer after consultation" with the accused. Id. $\$ 5.2(\mathrm{~b})$. The comments following these standards suggest, however, that the line is not nearly as clear as these standards indicate and, with regard to the defendant's decisions, the comment notes that "other significant decisions fall into a gray zone." 
give up this right simply because he has asked for the assistance of counsel..$^{59}$ But whatever the exact allocation of responsibility, counsel remains, as the Court said in Faretta, "an assistant" and "an assistant, however expert, is still an assistant."60

Aside from the constitutional restrictions, there are strong reasons in policy for requiring defense counsel to raise the competency issue. Experience with plea bargaining suggests that one ought to be skeptical of the notion that counsel will always act in the client's best interests. One study of plea bargaining concluded that because of the strong pressures that the system of plea bargaining places on defense attorneys, plea negotiations do not always result in an informed choice by the defendant despite the assistance of counsel and that "[f]ar from safeguarding the fairness of the plea negotiations, the defense attorney is himself a frequent source of abuse." 61 If, under our system, a competent defendant has little control over his attorney and the disposition of his case, the view that counsel should be permitted to proceed at his discretion with an incompetent client is upsetting indeed. ${ }^{62}$

\section{The Prosecutor}

Section 4244 imposes a duty upon the United States Attorney to raise the issue of competency whenever he has "reasonable cause to believe" that a defendant "may be" incompetent. ${ }^{63}$ It is not clear from the legislative history of section 4244 whether this provision was viewed as imposing a new duty on federal prosecutors or whether it was simply intended to codify a responsibility that had

59 It has been argued that Faretta should be read to undercut the traditional bar against mixed representation and that the defendant should be able to waive counsel for certain aspects of the trial while retaining counsel to conduct other aspects of the trial. See Chused, Faretta and the Personal Defense: The Role of a Represented Defendant in Trial Tactics, 65 CALIF. L. Rev. 636 (1977).

${ }^{60} 422$ U.S. at 820 . One of the few articles on competency that even suggests that counsel may have an obligation to raise competency is Chernoff \& Schaffer, Defending the Mentally Ill: Ethical Quicksand, 10 AM. CRIM. L. REv. 505, 515-20 (1972). The authors take a far more expansive view of the role of counsel than that argued in this article. They view the attorney who hesitates to raise the issue because it is contrary to his client's interests as placed in an ethical dilemma between his obligation to the court and his professional duty to represent his client effectively. Id. at 519.

it Alschuler, The Defense Attorney's Role in Plea Bargaining, 84 YaLe L.J. 1179, 1313 (1975). See also A. Rosett \& D. Cressey, Justice by Consent: Plea Bargains in the American Courthouse 137-43 (1976); Comment, In Search of the Adversary System-The Cooperative Practices of Private Criminal Defense Attorneys, 50 TEx. L. REv. 60, 112-13 (1971).

${ }^{62}$ As Bishop noted almost one hundred years ago, "Present insanity implies a disability to employ, control, or discharge counsel." 2 J. Bishop, Criminal Procedųre $\$ 666-4 d$ ed. 1880).

${ }^{63} 18$ U.S.C. $\S 4244$ (1970). 
existed at common law. ${ }^{84}$ Certainly the common law allowed others to raise the issue ${ }^{65}$ but whether the prosecutor had a specific duty to raise the issue is not clear.

Today, in the wake of several Supreme Court decisions ${ }^{66}$ holding that due process requires the prosecutor to bear responsibility for the fairness of the trial, a strong argument can be made that the prosecutor is under a duty, quite apart from section 4244 , to raise the issue of competency. In United States $v$. Agurs, ${ }^{67}$ the Court reaffirmed its position that a prosecutor violates his constitutional duty of disclosure under the due process clause of the fifth amendment when he fails to turn over exculpatory evidence, and that failure "is of sufficient significance to result in a denial of the defendant's right to a fair trial." 68 The standard set by the Court in Agurs for determining the significance of the undisclosed evidence is whether such evidence, in the context of the entire record, creates a reasonable doubt of guilt. ${ }^{69}$

The failure to raise competency, however, presents a somewhat different problem from that presented in Agurs and the other failure-to-disclose cases. First, evidence suggesting a serious competency problem may not be exculpatory; it may have very little to do with the crime. Second, cases such as Brady v._Maryland ${ }^{70}$ require the prosecutor to turn over exculpatory evidence, not to the court, but to the defense. By contrast the issue presented in relation to competency is whether the prosecutor must bring evidence of incompetency to the attention of the court. Should a prosecutor who has evidence of the defendant's incompetency have an obligation to raise competency even though that evidence is also in the possession of defense counsel?

The answer lies partly in one's view of the responsibility of the defense attorney when faced with a competency problem. If raising competency is viewed as a tactical move, then the prosecutor's obligation might be viewed as running only to defense counsel. On the other hand, if, as I have argued, defense counsel has an obligation

" Judge Magruder indicated that the provision "makes it more the specific duty of the Attorney General, and in the first instance of the United States Attorney, to bring this matter to the attention of the judge." Hearings, supra note 18, at 4 .

"sishop indicated that it was open even to "third persons" to raise the issue. See text and note at note 6 supra.

“ E.g., United States v. Agurs, 427 U.S. 97 (1976); Brady v. Maryland, 373 U.S. 83, 8688 (1963).

7427 U.S. 97 (1976).

"Id. at 108.

"Id. at 108, 112-13.

7 373 U.S. 83 (1963). 
to raise competency as part of a duty to protect his client's constitutional rights, no matter what the practical disadvantages a finding of incompetency might entail, then the prosecutor ought to have the same obligation in order to assure the fairness of the trial. The withholding of evidence going to the defendant's competency affects the fairness of the trial in a more fundamental sense than the withholding of exculpatory evidence. The government should not be permitted to explain its failure to raise competency by pointing to defense counsel's failure to raise the issue. In Evans $v$. Kropp ${ }^{71}$ a district court held that the prosecutor's failure to present evidence of incompetency to the trial judge prior to the acceptance of a guilty plea violated due process. The court indicated that the prosecutor had a duty to inform the court of such information. In the same opinion, the court further suggested that defense counsel's failure to raise the issue was tantamount to ineffective assistance of counsel, whether or not counsel viewed a finding of incompetency as favorable to his client.72

Cases such as Robinson, Drope, and even Youtsey, imply that if defense counsel fails to raise competency, it is nonetheless the court's obligation to raise and resolve the issue. By staunchly refusing to allow a remand in Drope for a retrospective determination of competency where the trial court failed to hold a hearing, the Supreme Court seems to be indicating a certain impatience with courts that fail to take control of the issue at the proper time. ${ }^{73}$ When one

7254 F. Supp. 218 (E.D. Mich. 1966) (McCree, J.).

72 But see Ashley v. Texas, 319 F.2d 80 (5th Cir. 1963), where the court held that the prosecutor violated due process by failing to inform defense counsel of information which suggested a competency problem. The information was viewed as a matter for the tactical use of counsel in planning a defense. Id. at 85 .

${ }^{73}$ The Supreme Court in Dusky v. United States, 362 U.S. 402 (1960), reversed the defendant's conviction because the district judge had used an improper standard to determine competency. In reversing and ordering a new trial the Court cited the "difficulties of retrospectively determining the petitioner's competency as of more than a year ago." Id. at 403. In Pate v. Robinson, 383 U.S. 375, 387 (1966), the Court also reversed, calling attention to the "need for concurrent determination" of the competency issue which the Court felt distinguished the case from Jackson v. Denno, 378 U.S. 368 (1964). Finally, in Drope v. Missouri, 420 U.S. 162 (1975), the "inherent difficulties of . . . a nunc pro tunc determination under the most favorable circumstances" were cited as the reason for refusing to remand to determine whether the petitioner had been competent at the time of his trial. 420 U.S. at 183. It seems more likely that the refusal to remand to allow the court to determine whether the defendant's prior competency can now be meaningfully determined is the Court's way of emphasizing the importance of the issue. The Court's actual justification for the refusal to remand makes little sense, since the "inherent difficulties" have not stopped a nunc pro tunc determination of the defendant's sanity at the time of the offense. In these cases there was a full trial and there may well be many reliable witnesses who observed the defendant or talked to him and who could offer testimony as to the defendant's mental abilities at trial.

The Court's remarks on the "inherent difficulties" of nunc pro tunc determinations of 
tion. ${ }^{79}$ Indeed, there may be very little relationship between a defendant's competency to stand trial and his criminal responsibility for the crime. A defendant may be seriously psychotic and not legally responsible for committing the crime and yet be fully able to understand the trial and assist in his defense. ${ }^{80}$ Moreover, competency is often determined on the basis of a single interview, ${ }^{81}$ while an examination into sanity at the time of the offense will involve far more testing, more interviewing or analysis, and more observation and evaluation than the competency inquiry ${ }^{82}$ Thus an examination into competency is an insufficient basis for making a determination of the defendant's criminal responsibility for the crime..$^{83}$

\section{A. Dual Purpose Examinations}

It is a common federal practice to order a "dual purpose examination" whenever competency is raised. This permits a psychiatrist to examine the defendant for the purpose of determining both his competency to stand trial and his sanity at the time of the offense. ${ }^{84}$

"See, e.g., Warren v. United States, 488 F.2d 862 (5th Cir. 1974).

* See United States v. Walker, 537 F.2d 1192 (4th Cir. 1976); United States v. Mercado, 469 F.2d 1148 (2d Cir. 1972).

"In many cases the interview on which the psychiatrist based his opinion was less than an hour. See, e.g., United States v. David, 511 F.2d 355, 359 (D.C. Cir. 1975) (30 minute interview); United States v. Taylor, 437 F.2d 371 (4th Cir. 1971) (10 minutes). Studies indicate that most examinations into competency could be conducted on an outpatient basis. See note 97 infra.

s2 See note 76 supra.

*3 Winn v. United States, 270 F.2d 326 (D.C. Cir. 1959).

\& There are no federal statistics on the exact scope of each examination because competency examinations are carried out not only at the Medical Center for Federal Prisoners in Springfield, Missouri, see, e.g., United States v. Fortune, 513 F.2d 883, 885 (5th Cir. 1975), but also by private psychiatrists at local private clinics, see, e.g., United States v. DiGilio, 538 F.2d 972, 986 (3d Cir. 1976), cert. denied sub nom. Lupo v. United States, 429 U.S. 1038 (1977), or at local government facilities, see, e.g., United States v. Reifsteck, 535 F.2d 1030, 1032 (8th Cir. 1976); United States v. Smith, 404 F.2d 720, 721-22 (6th Cir. 1968), and even in the defendant's cell, see, e.g., United States v. Taylor, 437 F.2d 371, 374 (4th Cir. 1971). Even the order that was entered is not always an indication of the nature of the examination carried out. See text at note 102 infra. But it is fairly easy to infer that dual purpose examinations are very common. In the first place, the statistics that do exist suggest that dual purpose examinations are the customary practice. See D.C. STuDY, supra note 10 , at 80 . Secondly, the practice of ordering dual purpose examinations has been consistently and repeatedly upheld by a number of circuits. See, e.g., United States v. Jines, 536 F.2d 1255, 1256 (8th Cir.), cert. denied, 429 U.S. 942 (1976); United States v. Wade, 489 F.2d 258 (9th Cir. 1973); United States v. Julian, 469 F.2d 371, 375-76 (10th Cir. 1972); United States v. Moudy, 462 F.2d 694, 697 (5th Cir. 1972). Thirdly, although the rationale for enlarging the scope of the competency examination to include criminal responsibility is that such an examination will provide economies of court time and medical effort, see text and note at note 94 infra, there has never been a requirement that there be a showing of any kind in order to obtain a dual purpose examination; it appears that courts are simply ordering such examinations routinely. In Winn v. United States, 270 F.2d 326 (D.C. Cir. 1959), Judge 
examines the Brady line of cases and the Court's attitude toward trial courts on the competency issue, it is evident that the Court would take a dim view of a prosecutor who had information raising a serious competency question but who failed to bring it to the attention of the trial court, regardless of whether such information was in the hands of defense counsel.

The source of the prosecutor's duty to disclose could be of great importance to the defendant. If the prosecutor's duty is statutory only, remedies for its breach need not necessarily take the form of vacating judgment. Criminal defendants are afforded more certain protection if breach of the duty is viewed as a denial of due process.

\section{The Psychiatric Examination and its Abuse}

Section 4244 provides that the court shall order a psychiatric examination once a motion raising the question of competency has been filed. Unless the motion is made in bad faith or is patently frivolous the court must order this examination. ${ }^{74}$ No preliminary inquiry into the defendant's competency is permitted..$^{75}$

As might be expected, the psychiatric examination into a defendant's competency to stand trial differs greatly from the examination into the defendant's criminal responsibility at the time of the offense. ${ }^{76}$ Different issues are at stake in the two inquiries. ${ }^{77}$ Unlike the insanity inquiry, nothing in the competency determination turns on the presence or absence of "a mental disease or defect." Instead, courts deal in a case by case fashion with the functional problems arising from, for example, amnesia ${ }^{78}$ and even drug addic-

competency have understandably led to some confusion in the circuits. The Fifth Circuit has remanded in certain cases where a hearing should have been held, leaving it up to the trial court to determine if an adequate and meaningful hearing into the defendant's prior competency is possible. See United States v. Makris, 483 F.2d 1082 (5th Cir. 1973); United States v. McEachern, 465 F.2d 833 (5th Cir.), cert. denied, 409 U.S. 1043 (1972). The Ninth Circuit has indicated that such a remand is not appropriate. United States v. Irvin, 450 F.2d 968 (9th Cir. 1971).

"Harkins v. Wyrick, 552 F.2d 1308, 1311 n.2 (8th Cir. 1977); United States v. Johnson, 527 F.2d. 1104, 1106 (4th Cir. 1975). This may be a matter of constitutional dimension. See text and notes at notes 163-164 infra.

${ }^{75}$ Rose v. United States, 513 F.2d 1251, 1255 (8th Cir. 1975); United States v. McEachern, 465 F.2d 833, 837 (5th Cir.), cert. denied, 409 U.S. 1043 (1972).

is See, e.g., United States v. Walker, 537 F.2d 1192 (4th Cir. 1976); Winn v. United States, 270 F.2d 326 (D.C. Cir. 1959); Blunt v. United States, 244 F.2d 355, 364 n.23 (D.C. Cir. 1957).

${ }^{71}$ See text and notes at notes 12-16 supra.

${ }^{78}$ In Wilson v. United States, 391 F.2d 460 (D.C. Cir. 1968), the defendant's amnesia was caused by the crash of the getaway car in which he was riding. See also United States ex rel. Parson v. Anderson, 481 F.2d 94 (3d Cir. 1973); United States v. Stevens, 461 F.2d 317 (7th Cir.), cert. denied, 409 U.S. 948 (1972). 
Originally courts turned to section 4244 as authority for ordering dual purpose examinations, but in recent years many of the circuits have come to accept the position that section 4244 is concerned only with competency. ${ }^{85}$ Considering the plain language of that section and the legislative history, the conclusion is inescapable that the legislators were concerned only with the problem of competency to stand trial..$^{86}$ As section 4244 has been discarded as authority for dual purpose examinations, courts have turned to their "inherent power" for the authority to expand the competency examination to cover insanity. ${ }^{87}$ The question, however, is not the power of the federal courts to order such examinations; long before section 4244 was passed, federal courts exercised the power to order psychiatric exams. The question is whether dual purpose exams are consistent with the defendant's constitutional rights and, even if they are, whether there are policy reasons against linking the insanity examination with the procedures for determining competency.

The defendant clearly receives no benefit from a dual purpose exam. Even if the defendant is indigent he can obtain his own psychiatric expert to provide those services "necessary to an adequate defense" pursuant to section $3006 \mathrm{~A}(\mathrm{e})$ of title 18 of the United States Code. ${ }^{88}$ Section $3006 \mathrm{~A}(\mathrm{e})$ contemplates a broad range of assistance including, but not limited to, expert testimony. ${ }^{89}$ Such an expert is available to help counsel evaluate possible defenses, and his conclusions need not be reported to the court or the prosecution. ${ }^{90}$ The section $3006 \mathrm{~A}(\mathrm{e})$ psychiatrist is, in a sense, part of the defense team.

There is no doubt that the main beneficiary of a dual purpose exam is the government, ${ }^{91}$ which employs the examination for dis-

Bazelon suggested that a prosecutor ought always to see that a dual purpose examination is conducted. Id. at 327-28.

${ }^{85}$ See, e.g., United States v. Jines, 536 F.2d 1255, 1256 (8th Cir.), cert. denied, 429 U.S. 942 (1976); United States v. Malcolm, 475 F.2d 420, 424 (9th Cir. 1973); United States v. Moudy, 462 F.2d 694, 697 (5th Cir. 1972).

sc See United States v. Alvarez, 519 F.2d 1036, 1042-44 (3d Cir. 1975). This case contains the best analysis of $\S 4244$ and its background.

${ }^{87}$ See, e.g., United States v. Jines, 536 F.2d 1255, 1256 (8th Cir.), cert. denied, 429 U.S. 942 (1976); United States v. Wade, 489 F.2d 258, 259 (9th Cir. 1973); United States v. Moudy, 462 F.2d 694 (5th Cir. 1972); Winn v. United States, 270 F.2d 326 (D.C. Cir. 1959).

8* United States v. Chavis, 476 F.2d 1137, 1141 (D.C. Cir. 1973); United States v. Taylor, 437 F.2d 371, 377 (4th Cir. 1971).

"See United States v. Caldwell, 543 F.2d 1333, 1350 (D.C. Cir. 1974); United States v. Taylor, 437 F.2d 371, 377 (4th Cir. 1971).

${ }^{90}$ United States v. Theriault, 440 F.2d 713, 715 (5th Cir. 1971), cert. denied, 411 U.S. 984 (1973). See also United States v. Alvarez, 519 F.2d 1036 (3d Cir. 1975) (privilege exists between defendant and his psychiatric expert).

"See text and notes at notes 93-94 infra. 
covery purposes. One cannot read current federal cases on insanity without being struck by the fact that, in case after case, the psychiatric expert called by the government to rebut the insanity defense is the same psychiatrist who was orginally employed to determine the defendant's competency to stand trial. ${ }^{92}$

Courts have on occasion frankly admitted that it is the government that benefits from dual purpose examinations. The Fifth Circuit in United States $v$. Moudy $y^{93}$ upheld a dual purpose exam ordered sua sponte by the trial court, and seemed to acknowledge that the purpose of such exams is government discovery:

In a sense, the discretion to enlarge the examination does, as appellant points out, expose him to the possibility of bolstering the government's case. But, in the end, all concerned-court, counsel, and parties-have an interest in determining if the accused was incompetent at the time of the offense, if that is to be an issue, and we see no prejudice in the court's ordering that said determination be made sooner rather than later and at a time when the determination is least likely to delay a trial. ${ }^{94}$

The court's rationale is surely a weak one. Whether or not the prosecution and defense have the same "interest" in determining if the defendant was insane at the time of the offense, they certainly do not have the same burden of proof. ${ }^{95}$ Yet the case stands as one of very few in which a federal court has given the practice of dual purpose exams other than the most cursory review. ${ }^{96}$

It is somewhat surprising that dual purpose examinations are routinely ordered without any showing of necessity, particularly in view of the consequences such an examination may have for the

${ }_{92}$ See, e.g., United States v. Reifsteck, 535 F.2d 1030 (8th Cir. 1976); United States v. Alvarez, 519 F.2d 1036 (3d Cir. 1975); United States v. McCracken, 488 F.2d 406 (5th Cir. 1974); United States v. Mattson, 469 F.2d 1234 (9th Cir. 1972), cert. denied, 410 U.S. 986 (1973); United States v. Bennett, 460 F.2d 872 (D.C. Cir. 1972).

${ }^{3} 462$ F.2d 694 (5th Cir. 1972).

it Id. at 697.

${ }^{25}$ In federal prosecutions, once a reasonable doubt of a defendant's sanity has been raised, the government has the burden of proving sanity. Davis v. United States, 160 U.S. 469 (1895). The only exceptions are prosecutions in the District of Columbia for which Congress in 1970 placed the burden of proving insanity on the defendant, by a preponderance of the evidence. 24 D.C. CoDE $\S 301(j)$ (1973). The District of Columbia Circuit has upheld the constitutionality of this statute. United States v. Greene, 489 F.2d 1145, 1153-56 (D.C. Cir. 1973), cert. denied, 419 U.S. 977 (1974). Exceptions such as this statute are permissible because, as the Supreme Court recently emphasized, Davis is not a constitutional ruling. Patterson v. New York, 97 S. Ct. 2319, 2323 (1977).

ss But see United States v. Alvarez, 519 F.2d 1036 (3d Cir. 1975). 
defendant's liberty. A competency examination can usually be performed on an outpatient basis, ${ }^{97}$ and should be conducted in a way that is least restrictive of the defendant's liberty ${ }^{88}$ Since an examination into sanity may require hospitalization for a substantial period of time, often amounting to several weeks, ${ }^{89}$ it is hardly unreasonable to require a showing of need before forcing a defendant to submit to a dual purpose examination when only questions of competency have been raised.

In any individual case a dual purpose order will achieve some savings in court time and will avoid the possible duplication of medical efforts if the defendant later raises the issue of his sanity at the time of the offense. However, studies indicate that of the numbers of defendants about whom there is a competency question, only a very small percentage will later raise an insanity defense. ${ }^{100}$ There is no dispute that competency questions are raised far more often than insanity. ${ }^{101}$ Thus, in routinely ordering dual purpose exams whenever competency is raised, courts are achieving a largely imaginary economy at great expense to defendants' liberties.

\section{B. The Problem of Notification: United States v. Driscoll}

One of the more serious problems with the current practice of ordering dual purpose examinations is the failure of the courts to give notice to defendant and his counsel of the fact that the examination will have any purpose other than determination of the defendant's competency to stand trial. Even if defense counsel made the original motion for a competency examination, counsel may be una-

$"$ D.C. STUDY, supra note 10 , at 81 . Studies have suggested that $70 \%$ of the evaluations on competency can be performed adequately on an outpatient basis. D. WeXLer, Criminal Commitments and Dangerous Mental Patients: Legal Issues of Confinement, Treatment, and Release 71 (DHEW Publ. No. (ADM) 76-331 (1976)). The Massachusetts Study has urged that all competency examinations should initially be done on an outpatient basis with observational admissions only if such examinations prove inadequate. MASSACHUSETTS STUDY, supra note 38 , at 65 .

"See generally Kaufman, Evaluating Competency: Are Constitutional Deprivations Necessary? 10 АM. CRIM. L. REv. 465, 473-77 (1972).

Several years ago the D.C. Circuit ruled that the defendant's competency should be determined on an outpatient basis when it has been requested unless it is shown that commitment is necessary for a proper diagnosis. Marcey v. Harris, 400 F.2d 772, 774 (D.C. Cir. 1968). The case has apparently had little effect, for it appears that St. Elizabeth's Hospital, which does most of the examinations in the District, is still not equipped to provide other than inpatient examinations. See United States v. Henry, 528 F.2d 661, 663 (D.C. Cir. 1976).

" The commitment period for such examinations often runs as long as 60 to 90 days. See

D.C. STUDY, supra note 10, at 29-30.

100 See MassachusetTs Study, supra note 38, at iii.

tol Id. 
ware that courts, in response to such a motion, commonly order a dual purpose examination. ${ }^{102}$ The problem is not always the fault of defense counsel. Often the order that is entered does not indicate the exact scope of the examination.

In United States $v$. Driscoll, ${ }^{103}$ the Second Circuit seemed to announce a notification rule. The trial court in that case ordered an examination into the competency of a defendant on trial for tax evasion. The order did not specify that the psychiatric examination would encompass both the issue of competency and the issue of criminal responsibility, but indicated only that a competency examination was to be conducted. ${ }^{104}$ The defendant was subsequently found competent, and the trial was commenced. At trial, the psychiatrist who had examined the defendant on the issue of competency testified for the government to rebut the defendant's claim that he was either insane, or, if not insane, then at least unable to entertain the wilfulness requisite to criminal liability. ${ }^{105}$ In an opinion that carefully skirted constitutional questions, the Second Circuit, in its supervisory capacity, reversed, holding that it was unfair to use the psychiatrist's testimony against the defendant at trial without giving adequate notice of that possibility prior to the examination. ${ }^{106}$ The court stated: "We do not believe that a defendant can be told that he is to be examined for one purpose and, once his cooperation has been obtained, be advised of another." 107

What is surprising about Driscoll is the narrowness of the holding. When a court order specifies one purpose for the examination, it would seem to be a violation of due process to permit the government, without notice to either counsel or the defendant, to obtain discovery on other issues. The Driscoll court pointed out that if counsel had been given notice of the dual purpose of the examination, he might have sought certain procedural protections, such as the presence of counsel or taping of the examination. ${ }^{108}$ Although the federal courts have consistently held that a defendant has no right to counsel at these examinations, ${ }^{109}$ the rationale underlying a right

102 See, e.g., United States v. Malcolm, 475 F.2d 420, 422 (9th Cir. 1973).

${ }^{103} 399$ F.2d 135 (2d Cir. 1968).

tos Id. at 137.

${ }^{105}$ Id. at 136-37.

108 Id. at 138.

${ }^{107}$ Id. at 137 .

${ }^{108}$ Id. at 138.

${ }^{109}$ United States v. Mattson, 469 F.2d 1234, 1236 (9th Cir. 1972), cert. denied, 410 U.S. 986 (1973); United States ex rel. Stukes v. Shovlin, 464 F.2d 1211, 1213 (3d Cir. 1972); United States v. Smith, 436 F.2d 787, 790 (5th Cir. 1971). In Lee v. County Court, 27 N.Y.2d 432, 267 N.E.2d 452, 318 N.Y.S.2d 705, cert. denied, 404 U.S. 823 (1971), the New York Court of 
to notice in these situations is not that counsel, if notified, could have prevented the examination or attended it. The main concern is that counsel should be entitled to explain to his client the nature of the examination and its possible legal consequences. When the order misleads counsel, it places him in the position of misrepresenting the nature of the examination to his client. ${ }^{110}$ To force a defendant, who may be emotionally unstable, to submit to a more intensive and probing mental examination, without warning to defense counsel, is troubling, particularly when the examination may produce adverse psychological consequences. ${ }^{111}$

Even though Driscoll was only a very cautious step in the direction of controlling the use of dual purpose examinations, the Second Circuit, only nine months later, expressed some dissatisfaction with the case. ${ }^{112}$ Two circuits have specifically rejected Driscoll, ${ }^{113}$ and it appears that Driscoll remains good law only in the Third Circuit. ${ }^{114}$

\section{Self-Incrimination Problems: Statutory and Constitutional}

The Driscoll court appeared to hold it reversible error to permit the psychiatrist who examined a defendant on the issue of competency to testify at trial against the defendant on the issue of insanity, if the court failed to notify the defendant that the competency examination would be used to gather trial evidence. In United States $v$. Alvarez, ${ }^{115}$ the Third Circuit suggested that the use of

Appeals ruled that the defendant had the right to the presence of counsel to act as an observer. Id. at 444,267 N.E.2d at $458-59,318$ N.Y.S.2d at 714-15.

110 The court in Driscoll stated that the "defendant was entitled to notice so that he could consult with counsel beforehand and thereafter fully and intelligently respond to the doctor's questions." 399 F.2d at 138.

II' See Smith, Psychiatric Examinations-Federal Mental Competency Proceedings, 37 F.R.D. 111 (1964).

"12 In United States v. Matos, 409 F.2d 1245 (2d Cir. 1969), the court refused to extend Driscoll to condemn the government's use of evidence based on a psychiatric examination conducted by state and city officials for purposes unrelated to the federal prosecution. Defendant claimed that Driscoll barred the use of the psychiatric evidence because he had not been wanned at the time of the examination that it might be used against him on the issue of sanity at trial. The court declared that Driscoll "should be limited strictly to its own facts." Id. at 1247 n.2. The remark is somewhat cryptic. On the one hand, the court may simply have meant that Driscoll only mandates notification in dual purpose competency examination cases. On the other hand, the court may have meant that Driscoll presented an extraordinary case of deceit by the government that warranted extraordinary relief. The court distinguished the Matos case from Driscoll on the grounds that Matos presented "no element of deceit or unfairness such as would warrant excluding the psychiatric testimony in this case." Id. at 1247.

i3 United States v. Mattson, 469 F.2d 1234 (9th Cir. 1972), cert. denied, 410 U.S. 986

(1973); United States v. Jacquillon, 469 F.2d 380 (5th Cir. 1972).

iil See United States v. Alvarez, 519 F.2d 1036, 1044 (3d Cir. 1975).

115519 F.2d 1036 (3d Cir. 1975). 
statements made by a defendant during the course of a psychiatric examination conducted pursuant to section 4244 would raise "a fifth amendment problem of no little difficulty."116

In Alvarez, a defendant charged with kidnapping raised the question of competency, was examined pursuant to section 4244, and was found competent to stand trial. At trial, the psychiatrist who examined the defendant on the competency question was called to testify in rebuttal to the defendant's insanity defense. The court of appeals noted that the psychiatrist, "clearly the most effective government witness on that issue," 117 recounted statements by the defendant that, while denying involvement in the crime, indicated that "he knows that it was wrong." 118 Without deciding whether courts possessed the "inherent power" to compel psychiatric examinations on the insanity issue, the Third Circuit recognized that the use on the insanity issue of statements elicited at the competency examination raises fifth amendment problems. Previous cases in the circuit had ruled that "at least where any statement elicited in the examination tends to establish the fact of the offense or the voluntariness of other statements by the accused, [it] is a violation of the privilege against self-incrimination."110 In light of these precedents, the court in Alvarez concluded that "it would be quite difficult to hold that statements elicited in a compelled psychiatric examination could be used to establish sanity, and thus guilt." ${ }^{120}$ The court avoided the constitutional issue, however, and reversed on statutory grounds, ruling that section 4244's bar against the use of statements made by the accused at the competency examination "on the issue of guilt in any criminal proceeding" 121 forecloses the use of such statements on the issue of sanity at trial.

As the Alvarez court noted, section 4244 was drafted in such a

is Id. at 1041.

sir Id.

${ }^{118} I d$.

111 Id. at 1042.

120 Id. The Third Circuit in Government of the Virgin Islands v. Bellott, $495 \mathrm{~F} .2 \mathrm{~d} 1393$ (3d Cir. 1974), held that sanity is an issue concerning guilt and thus is an issue which the government bears the burden of proving beyond a reasonable doubt.

121 The statute provides, in relevant part:

No statement made by the accused in the course of any examination into his sanity or mental competency provided for by this section, whether the examination shall be with or without the consent of the accused, shall be admitted in evidence against the accused on the issue of guilt in any criminal proceeding.

18 U.S.C. § 4244 (1970).

The D.C. statute on competency has no such exclusionary provision, but the D.C. Circuit has held that the $\S 4244$ prohibition applies to examinations carried out under 24 D.C. CODE $\S 301$ (1973). See United States v. Bennett, 460 F.2d 872, 878 n.22 (D.C. Cir. 1972). 
way as to avoid fifth amendment problems. In addition to the provision against admission of the defendant's statements in the competency examination, section 4244 provides that a finding of competency "shall in no way prejudice the accused in a plea of insanity as a defense to the crime charged; such a finding shall not be introduced in evidence on that issue nor otherwise be brought to the notice of the jury."122 This language was added to the proposed section 4244 by the Senate Judiciary Committee ${ }^{123}$ just prior to passage in order "to give adequate assurance to an accused person that his right to plead insanity will be protected." 124 Far from authorizing a new method for facilitating government discovery, the thrust of these amendments to section 4244 was to avoid fifth amendment difficulties and protect the defendant's trial options.

Section 4244, however, does not in terms bar the psychiatrist from testifying at trial against the defendant on the issues of insanity or mens rea. In United States $v$. Malcolm, ${ }^{125}$ the Ninth Circuit relied on the absence of such a specific prohibition to reject the defendant's argument that permitting the psychiatrist to testify at trial violated section 4244 . The court stated:

Congress could have resolved the matter by forbidding the examining psychiatrist from testifying at the trial on the merits, but it did not do so. It chose instead to frame the limitation in terms of statements made by the accused. If the examining psychiatrist does not testify to the statements by the accused, his testimony is not foreclosed by $\S 4244 .{ }^{128}$

The Malcolm rationale is questionable in two respects. First,

12218 U.S.C. $\S 4244$ (1970). With regard to this provision that a finding of incompetency shall not be introduced or otherwise "brought to the notice of the jury," the courts have faced problems of interpretation because often it becomes evident that the psychiatrist was originally appointed by the court to examine both competency and insanity. See, e.g., United States v. Harper, 450 F.2d 1032, 1035-36 (5th Cir. 1971). The provision has now been narrowly interpreted so as to bar only the admission of the court's finding of competency. Id. Even though such a finding by the court would be clearly implied, courts have permitted psychiatrists to mention the nature of their appointment and even allowed into evidence on the sanity issue psychiatric reports which concluded that the defendant is competent. See United States v. Hereden, 464 F.2d 611 (5th Cir. 1972); United States v. Harper, 450 F.2d 1032 (5th Cir. 1971).

12s Judge Calvert Magruder was the main witness at the Senate Judiciary Committee hearing on the bill. The Committee Chairman Alexander Wiley showed an impressive knowledge of the general law in the area and he pressed Judge Magruder on a number of procedural points. See Hearings, supra note 18, at 4-11.

12: Care and Custody of Insane Federal Prisoners, S. Rep. No. 1511, 80th Cong., 2d Sess. 1 (1948).

${ }_{125} 475$ F.2d 420 (9th Cir. 1973).

120 Id. at 426. 
section 4244 was drafted to allow an examination dealing only with competency. As long as the examination was limited to competency, there was no reason for Congress to be concerned about the use of the psychiatrist as an expert witness against the defendant on the issue of insanity. One cannot fault Congress for failing to surround with special protections an examination that was not intended to fall within the scope of section 4244 . Second, the court's notion that 4244 only bars the introduction of defendant's statements as such seems inaccurate. To contend that the psychiatrist may testify freely at the trial on the basis of the defendant's compelled statements ignores the spirit of the protections provided by section 4244 and results in "prejudice" to the defendant's insanity defense.

Whether or not dual purpose examinations are consistent with section 4244 , there remain the substantial fifth amendment problems alluded to by the Alvarez court. The question of the constitutionality of compelled psychiatric examinations in connection with criminal proceedings is unresolved in the federal courts, perhaps due in part to the phenomenon of the dual purpose examination, which has enabled the government to obtain discovery on insanity questions in an indirect manner. ${ }^{127}$ The fifth amendment basically protects defendants in criminal trials from being compelled to testify against themselves. The Supreme Court has attempted to define the limits within which a defendant cannot be compelled to cooperate by differentiating between testimonial evidence, which is protected, and "real" or essentially physical evidence, which does not fall within the privilege. ${ }^{128}$ Using this distinction, some courts have suggested the psychiatric examinations do not raise fifth amendment problems because they do not compel communications at all but instead produce physical evidence like blood tests, lineups, handwriting exemplars, and voice identifications. ${ }^{129}$ However, as one commentator noted, the notion that the psychiatrist seeks "physical evidence" is belied by the fact that the usual examination is designed to "discover certain types of ideas and thought processes .. . by eliciting verbal, emotional and physical indications" of the subject's ideas. ${ }^{130}$

${ }^{122}$ See text at notes 93-94 supra.

12x See generally Lefelt, Pretrial Mental Examinations: Compelled Cooperation and the Fifth Amendment, 10 Am. CRIM. L. Rev. 431, 434 (1972).

${ }^{220}$ See, e.g., United States v. Cohen, 530 F.2d 43, 48 (5th Cir. 1976); United States v. Handy, 454 F.2d 885, 889 (9th Cir. 1971).

${ }_{130}$ See Note, Requiring a Criminal Defendant to Submit to a Government Psychiatric Examination: An Invasion of the Privilege against Self Incrimination, 83 HARv. L. REv. 648, 655 (1970). 
Not only does a psychiatric examination elicit information that seems closer to "testimonial" than real evidence, but the method of conducting the examination also seems to conflict with the values intended to be protected. Among the reasons for the privilege are (1) the need to protect the defendant from possible inhuman treatment; (2) the unreliability of compelled confessions; (3) respect for the human dignity of the accused; (4) unwillingness to put an individual to a choice between self-incrimination, perjury, or contempt; and (5) a rejection of inquisitorial procedures. ${ }^{131}$ The psychiatric examination seems to threaten many, if not all, of the values underlying the privilege. The possibility of inhuman treatment in the form of psychological coercion, problems of reliability, ${ }^{132}$ impingement on the defendant's innermost private thoughts, the temptation to feign insanity-all of these evils inhere in compelled psychiatric examinations.

The cases that have examined the problem have not recognized these considerations and have simply offered a series of conclusory and inconsistent justifications for upholding the use of testimony based on compelled psychiatric examinations. It has been suggested, for example, that compelled psychiatric examinations do not raise fifth amendment problems so long as the psychiatrist avoids repeating the defendant's statements, ${ }^{133}$ or that compelled psychiatric examinations do not raise fifth amendment problems because the purpose of the exam is not to prove that the defendant did the act, but to determine whether he "possesses the requisite mentality to be guilty as charged . . .."134

$13 t$ See id. at 656.

132 A defendant who may be perfectly sane has the incentive to try to fool the psychiatrist into believing he is insane, while one characteristic of the mentally ill is that they try to guard against disclosing their illness. Id. at 658 .

${ }^{133}$ See, e.g., United States v. Jines, 536 F.2d 1255 (8th Cir.), cert. denied, 429 U.S. 942 (1976).

is United States v. Albright, 388 F.2d 719, 723 (4th Cir. 1968).

The Advisory Committee Note to FED. R. CRIM. P. 12.2 indicates that compelled psychiatric exams do not raise fifth amendment problems because "[a]ny issue of selfincrimination which might arise can be dealt with by the court as, for example, by a bifurcated trial which deals separately with the issue of guilt and of mental responsibility." But this rests on the assumption that guilt and mental responsibility are separable issues-an assumption which has been subjected to considerable attack. See generally Louisell \& Hazard, Insanity as a Defense: The Bifurcated Trial, 49 CaLIF. L. Rev. 805 (1961). In State v. Shaw, 106 Ariz. 103, 471 P.2d 715 (1970), cert. denied, 400 U.S. 1009 (1971), the Arizona Supreme Court held that the exclusion, at the trial on guilt, of evidence of partial impairment which showed that the defendant was not capable of forming the intent required for the crime violated due process-even though such evidence might be considered at the trial on insanity. The court held that the Arizona bifurcated trial statute was unconstitutional because it prevented the defendant from showing he did not have the requisite intent. 
All of the arguments advanced have a forced quality about them and have been subject to much criticism in the extensive literature on compelled psychiatric examinations and insanity. ${ }^{335}$ One view of the fifth amendment and compelled psychiatric exams deserves discussion for it seems to be the most common view and it takes the most realistic approach to the problems involved. According to this view, when a defendant raises an insanity defense and relies on experts to support that defense, the government is entitled to have the defendant examined by its own experts in order to meet the defense. ${ }^{136}$ The theory seems to be that, by opening himself to his own experts and offering those experts at trial, the defendant waives his fifth amendment privilege to resist a similar examination by government experts. ${ }^{137}$ It is argued that the maintenance of a "fair state-individual balance" permits such an examination because of the nature of the insanity defense; if the government is required to prove sanity beyond a reasonable doubt, "it cannot be denied access to the only reliable means of ascertaining the truth concerning a defendant's sanity." ${ }^{138}$

This theory appears to be embodied in rule 12.2 of the Federal Rules of Criminal Procedure. Rule 12.2 requires a defendant to give: (a) notice of his intention to rely on the insanity defense, and (b) notice of his intention to use expert testimony relating to mental disease or mental state. The rule also authorizes the court to condition the defendant's use of expert testimony on his willingness to submit to a psychiatric examination if the government moves for an examination. 139

Even if a defendant's intention to use expert testimony on issues of insanity or mens rea can be deemed a "waiver" of the fifth amendment privilege, there is nothing that triggers such a waiver when competency questions are raised. While defense counsel may have raised the question of competency, the court should not con-

13 See, e.g., Note, Requiring a Criminal Defendant to Submit to a Government Psychiatric Examination: An Invasion of the Privilege Against Self-Incrimination, 83 Harv. L. REv. 648 (1970). See also Danforth, Death Knell for Pre-Trial Mental Examination? Privilege against Self-Incrimination. 19 RuTGERS L. REv. 489 (1965).

${ }^{138}$ See, e.g., Karstetter v. Caldwell, 526 F.2d 1144 (9th Cir. 1975); United States v. Baird, 414 F.2d 700, 710 (2d Cir. 1969), cert. denied, 396 U.S. 1005 (1970); United States v. Albright, 388 F.2d 719 (4th Cir. 1968); Alexander v. United States, 380 F.2d 33, 39 (8th Cir. 1967). The leading case on this view is a state case, State v. Whitlow, 45 N.J. 3, 210 A.2d 763 (1965).

${ }_{137}$ The theory appears to be a waiver theory but it is not exactly clear. See United States v. Malcolm, 475 F.2d 420, 425 (9th Cir. 1973). At times it appears in the form of an estoppel argument. See, e.g., United States v. Weiser, 428 F.2d 932, 936 (2d Cir. 1969).

133 United States v. Albright, 388 F.2d 719, 724 (4th Cir. 1968).

139 FED. R. CRIM. P. 12.2. 
sider this to be an indication of the defendant's future trial strategy with regard to raising and proving an insanity defense. ${ }^{1+0}$ Moreover, for a court to interpret the motion for a competency hearing as a waiver would seem to ignore the fact that what is being raised is the present ability or inability of the defendant either to assert or to waive his rights.

The fundamental constitutional problem does not, of course, inhere in dual purpose examinations as such, but in compelled psychiatric examinations. ${ }^{111}$ The consistency of such examinations with the privilege against self-incrimination is not at all clear, complicated as the issue is by questions concerning the uses of expert psychiatric testimony in federal courts ${ }^{1 / 2}$ and the role of trial courts in raising the insanity defense sua sponte. ${ }^{143}$ The difficulties are only compounded when the competency examination is used for discovery purposes.

140 See text and note at note 94 supra.

ill The use of dual purpose examinations may, however, raise more serious fifth amendment problems than the compulsion of psychiatric examinations pursuant to rule 12.2. Rule 12.2 does not authorize courts to order examinations on the sanity issue. Rather it permits the court to condition defendant's use of expert testimony upon his submission to examination by the prosecution's experts. This has been upheld as a permissible burden on the privilege against self-incrimination. Karstetter v. Caldwell, 526 F.2d 1144 (9th Cir. 1975); Alexander v. United States, 380 F.2d 33 (8th Cir. 1967). Under $\$ 4244$, however, the accused has no choice but to submit. The competency examination is to be conducted "with or without the consent of the accused." 18 U.S.C. $\$ 4244$ (1970). If the competency examination is dual purpose, the privilege is not merely burdened, it is denied.

is2 The admissibility of expert testimony upon the issue of mens rea in federal courts is unclear. See Advisory Committee Note to FED. R. CRIM. P. 12.2, 62 F.R.D. 295-98 (1974). Compare Rhodes v. United States, 282 F.2d 59, 62 (4th Cir. 1960), with Fisher v. United States, 328 U.S. 463 (1946). It appears that trial courts have wide latitude on the decision whether or not to admit expert testimony directed to the capacity of a defendant to entertain the specific intent that is an element of the crime. United States v. Demma, 523 F.2d 981, 986 (9th Cir. 1975).

is The District of Columbia Circuit Court of Appeals has ruled that even if a defendant who is competent refuses to raise the defense of insanity, the trial court may itself submit the insanity defense to the jury. See Whalem v. United States, 346 F.2d 812 (D.C. Cir.), cert. denied, 382 U.S. 862 (1965). This involves a serious interference by the court with trial strategy and the sort of decision a court is ill-equipped to make. The American Law Institute rejected such a proposal "as being too great an interference with the conduct of the defense." Model Penal Code $\$ 4.03$ Comment (Tent. Draft No. 4, 1955). It places defense counsel in an impossible position, caught between the wishes of his client and the court. See 53 TEx. L. REv. 1065, 1071-72 (1975).

The D.C. Circuit has stressed that the decision to raise insanity sua sponte should be made only after a full presentation of all the testimony, including medical expert testimony, related to criminal responsibility. See United States v. Robertson, 507 F.2d 1148 (D.C. Cir. 1974). In Robertson, dual purpose examinations gave the trial court such information on sanity. Id. at 1151. 


\section{Further Problems}

Even if a court may order a compulsory examination into sanity before the defendant has given notice that he intends to raise the insanity defense and rely on expert testimony, there are important reasons for keeping the competency and sanity examinations separate.

First, there is much confusion among lawyers concerning the distinction between competency and insanity. ${ }^{144}$ Indeed, some defense lawyers are under the impression that section 4244 is the proper means for obtaining psychiatric assistance for a possible insanity defense. ${ }^{145}$ Studies indicate that these attorneys are often unaware of the common law criteria for competency. ${ }^{146}$ Whatever may be the defendant's statutory or constitutional rights with respect to psychiatric examination by the government, it is patent that those rights cannot be asserted if defendant's counsel misunderstands the nature of the proceedings. Merging the insanity and competency issues in a single examination further blurs the distinction and exacerbates the confusion.

A problem that is perhaps more serious is that such examinations alter the nature of the competency proceedings and the role of the psychiatrist. In theory, neither the government nor the defense is entitled to a psychiatrist under section 4244 . The appointed psychiatrist is supposed to be the court's expert; section 4244 provides that he "shall report to the court." 147 The cases refer to the psychiatrist under section 4244 as "an impartial expert," 148 "an officer of the court, not responsible to the prosecution or the defense."149

ist The confusion that exists among lawyers over the nature of competency is also evident among psychiatrists. Some have tended to equate competency with mental disease or with criminal responsibility. See generally McGarry, Demonstration and Research in Competency for Trial and Mental Illness: Review and Preview, 49 B.U. L. Rev. 46, 50 (1969); Roby, Criteria for Competency to Stand Trial: A Checklist for Psychiatrists, 122 AM. J. PsycH. 616, 617 (1965); Settle \& Oppegard, The Pre-Trial Examination of Federal Defendants, reprinted in Oliver, Application of Psychiatry to Study, Observation, and Treatment of the Federal Offender, 35 F.R.D. 381, 479-80 (1964). This tendency to confuse the issues is reinforced by asking both questions together.

is See, e.g., United States v. Walker, 537 F.2d 1192, 1194 (4th Cir. 1976); United States v. Theriault, 440 F.2d 713, 714 (5th Cir. 1971), cert. denied, 411 U.S. 984'(1973); United States v. Taylor, 437 F.2d 371, 377 n.8 (4th Cir. 1971).

Is The Massachusetts Study concluded that "[t]he majority of defense counsel interviewed in this project were not aware of the common law criteria for competency to stand trial." Massachusetrs Study, supra note 38 , at 6 . The same study also concluded that a confusion between criminal responsibility and competency existed in many American jurisdictions. Id.

17718 U.S.C. $\$ 4244$ (1970).

148 United States v. Green, 544 F.2d 138, 145 (3d Cir. 1976).

is United States v. Pogany, 465 F.2d 72, 78 (3d Cir. 1972). 
$\mathrm{He}$ is expected to be "neutral and detached"150 and "to serve the court in a completely nonpartisan manner." 151 "An advocacy role," it is said, "would be inconsistent with a fair and impartial determination." 152 I shall argue in Section III that the nature of the competency inquiry makes it important that a court have the assistance of its own psychiatrist or psychiatrists. Yet to leave the appointment up to the court is not wholly satisfactory given that identifications with different schools and value systems make the notion of an "impartial" psychiatric expert largely illusory. ${ }^{153}$ Whatever weaknesses the system of appointments under section 4244 has, broadening the psychiatrist's role to include what may be the major trial issue-the question of insanity-magnifies these problems. The court's expert in this situation begins to look exactly like the government's expert. There are disturbing indications that the government has a degree of control over the nature of the examination that is inconsistent with the notion that the psychiatrist shall not be "responsible to the prosecution." 154 This has resulted because government prosecutors have come to view competency proceedings as an opportunity for discovery. ${ }^{155}$ This practice, furthermore, has been encouraged by Justice Department policy. ${ }^{156}$
150 United States v. Stern, 519 F.2d 521, 526-27 (9th Cir. 1975).
15 United States v. Caldwell, 543 F.2d 1333, 1350 (D.C. Cir. 1974).
132 United States v. Pogany, 465 F.2d 72 (3d Cir. 1972).
153 Goldstein \& Fine, The Indigent Accused, the Psychiatrist, and the Insanity Defense,

110 U. PA. L. Rev. 1061, 1072-73 (1962).

134 See, e.g., United States v. Henry, 528 F.2d 661, 663 (D.C. Cir. 1976); United States v. Pogany, 465 F.2d 72, 77-78 (3d Cir. 1972). See generally Chernoff \& Schaeffer, Defending the Mentally Ill: Ethical Quicksand, 10 AM. CRM. L. REv. 505, 509-10 (1972).

${ }^{135}$ See Krash, The Durham Rule and Judicial Administration of the Insanity Defense in the District of Columbia, 70 Yale L.J. 905, 911 (1961).

156 The United States Attorney's Manual states:

When the examination [for competency] is to be made locally, the order for examination should also direct that the examiner render an opinion as to the accused's mental responsibility at the time of the alleged offense, if the U.S. Attorney believes that, in addition to a determination of competency, an examination as to mental responsibility at the time of the offense will effect a savings in trial time or would be otherwise beneficial in the trial or other disposition of the case. The opinion on the accused's mental responsibility at the time of the offense . . . is to be obtained in cases of local examinations in view of the fact that the local doctors will be available for testimony on this issue.

Criminal Division, United States Attorney's Manual ch. 9, at 2 (Aug. 1, 1977). But see United States v. Alvarez, 519 F.2d 1036, 1044 (3d Cir. 1975).

Because competency is usually raised very early in the proceedings, even prior to indictment, it will often turn out that the dual purpose exam will take place well before the defendant has been examined by his own psychiatrist for purposes of considering an insanity defense. That may mean that additional credibility will attach to the earlier exam since it may be considerably closer to the crime. See Hughes v. United States, 306 F.2d 287, 290 (D.C. Cir. 1962). 
If dual purpose examinations encourage prosecutors to raise competency, they deter defense attorneys from raising the question. I have argued that a defense attorney who believes that his client may be incompetent is under an obligation to so inform the court, even if the attorney feels that a finding of incompetency would be against his client's interest. ${ }^{157}$ Obviously a competency motion may strain the attorney-client relationship in certain circumstances. It may even be the case that the client is opposed to raising the issue. ${ }^{158}$ The use of dual purpose examinations aggravates the problem by turning counsel's motion into an opportunity for government discovery. Counsel's lot is hard enough without forcing him to risk producing evidence against his client that could be used to rebut an insanity defense or to prove mens rea.

Traditionally, competency has been viewed as a special issue that demands that "the proceedings should stop" until competency was resolved. ${ }^{159}$ The injection of trial issues such as the insanity defense into the competency question is inconsistent with that tradition and ought not to be permitted.

\section{The Hearing}

\section{A. The Decision to Hold a Hearing}

Section 4244 provides for a hearing if the psychiatric report indicates that the defendant may be incompetent. Unfortunately, section 4244 does not require the court to examine the defendant in every case in which competency is properly raised. If the psychiatrist's report indicates that the defendant is competent, neither a hearing on the question nor a finding by the court will be required. ${ }^{160}$ By allowing the need for a hearing to be determined by the psychiatrist's conclusion as to the defendant's competency, section 4244 encourages the court to give far too much weight to the bottom line of the psychiatrist's report. The ultimate legal determination should be for the court, not the psychiatrist; psychiatric reports are weakest precisely at the point of drawing legal conclusions from clinical data. ${ }^{161}$

137 See text and notes at notes 43-62 supra.

İ* See, e.g., United States v. David, 511 F.2d 355, 358 (D.C. Cir. 1975).

159 Youtsey v. United States, 97 F. 937, 941 (6th Cir. 1899).

${ }_{160}$ United States v. Marshall, 458 F.2d 446 (2d Cir. 1972); Stone v. United States, 358 F.2d 503, 506 (9th Cir. 1966); Arnold v. United States, 432 F.2d 871 (10th Cir. 1970); Whalem v. United States, 346 F.2d 812, 816 (D.C. Cir. 1965).

16 See McGarry, supra note 144, at 58-59. For this reason, the test developed in the Massachusetts Study draws no conclusion with regard to competency but leaves it up to the 
To allow the court to dispense with a hearing when the psychiatrist's report indicates that the defendant is competent may raise a constitutional problem. Pate $v$. Robinson ${ }^{162}$ seems to suggest that due process demands a hearing once competency is properly raised. In Robinson, the Supreme Court of Illinois had ruled that the evidence of incompetency was not sufficient to require a hearing, primarily because the defendant had displayed sufficient mental alertness and understanding during the trial to warrant the judge's conclusion that a hearing was unnecessary. ${ }^{163}$ The Supreme Court reversed, holding that although the defendant's demeanor at trial might be relevant to the ultimate determination, the court could not simply dispense with a hearing. ${ }^{164}$

The Supreme Court may have intended to limit its holding in Robinson to the situation in which the judge ignores reliable evidence on the question of competency and, solely on the basis of his own limited observations, refuses to order a hearing. On the other hand, the decision may have broader application, implying that the summary dismissal of the question of competency based on only one piece of evidence would violate due process. Even if the decision rested on the unreliability of the judge's observations, it could be argued that the psychiatric report-given the limitations of psychiatry as a science-is sufficiently fallible that a hearing should be required even when the report concludes that the defendant is competent. Although federal courts have not viewed Robinson as creating a right to a hearing in all cases where competency has been properly raised, ${ }^{165}$ it nonetheless seems unwise to rely exclusively on the psychiatric report, particularly when only one psychiatrist has examined the defendant. ${ }^{166}$

B. The Nature of the Hearing: Roles of the Court, Psychiatrist, and Prosecution

Once it has been determined that a hearing is necessary, the courts are given wide discretion with regard to the type of evidence to be presented. Section 4244 provides that "evidence as to the mental condition of the accused may be submitted, including that

court to weigh the defendant's inabilities in the context of the particular case. MASSACHUSETTS Srudy, supra note 38 , at 98 ; see note 170 infra.

162383 U.S. 375 (1966).

${ }^{163}$ Id. at $385-86$.

ist Id. at 386.

us See, e.g., United States v. Marshall, 458 F.2d 446, 450 (2d Cir. 1972); Arnold v. United States, 432 F.2d 871, 874 (10th Cir. 1970).

ist See text and note at note 153 supra. 
of the reporting psychiatrist. . . ."167 Clearly, the main witnesses at the hearing should be the psychiatrist (or psychiatrists) and the defendant. Unlike his role in the context of an insanity defense or civil commitment proceeding, however, the psychiatrist's role at the competency hearing should not be dominant. On the contrary, the court is the body responsible for deciding the issue and it should not consider the psychiatrist's report as controlling, but simply as one piece of evidence on the issue.

For several reasons the court may be in a better position to decide the issue than the psychiatrist. First, neither the presence of a "mental disease or defect" nor the prediction of "dangerousness" is necessarily an important factor in determining competency. Although the psychiatrist may expose the existence of certain mental deficiencies, the court can better evaluate the effect such deficiencies will have on the formulation of a defense. ${ }^{168}$ Secondly, the major concern in the competency hearing is the defendant's "present" mental condition. Unlike the psychiatrist who may only examine the defendant once, the court can continuously evaluate the defendant's present abilities throughout the trial proceedings. Finally, the court's inquiry into the defendant's competency is similar to the type of inquiry that a court routinely makes in ensuring the voluntariness of a plea. Although an inquiry into the defendant's understanding of the criminal process will generally be more detailed and careful in a competency hearing, ${ }^{169}$ it is a type of inquiry with which a court should be familiar. ${ }^{170}$

18718 U.S.C. $\$ 4244$ (1970).

${ }^{185}$ This may be one reason why $\$ 4244$ only requires examination of the defendant by a single psychiatrist selected by the court. Section 4247 , part of the 1949 act that included $\S$ 4244 , deals with the commitment of prisoners who "probably endanger the safety" of the officers, property, or interests of the United States. In contrast to $\S 4244, \S 4247$ allows the prisoner to select one of the examining psychiatrists prior to the hearing on dangerousness. 18 U.S.C. \$ 4247 (1970).

183 Pursuant to rule 11 of the Federal Rules of Criminal Procedure, a court is required to conduct an inquiry prior to the defendant's acceptance of a plea. This inquiry is not sufficient for determining the competency of the defendant. United States v. Masthers, 539 F.2d 721, 728-29 (D.C. Cir. 1976). It is an inquiry undertaken solely to determine the voluntariness of the plea; the defendant's competency is assumed.

170 The court's inquiry should include whether the defendant is able: (1) to understand the charges; (2) to understand the defenses available to him; (3) to distinguish between a plea of guilty and a plea of not guilty; (4) to understand the basic essentials of criminal trial proceedings; (5) to follow the evidence; (6) to take the witness stand and testify coherently; (7) to assist counsel in evaluating the testimony of witnesses; and (8) to recall facts concerned with the time of the alleged violation. Weiter v. Settle, 193 F. Supp. 318, 321 (W.D. Mo. 1961). The examinations that have been developed by psychiatrists concerned with the problem of competency have been aimed at giving the court information on such factors. See Roby, supra note 144, at 618 . The Massachusetts Study developed a test which measures the 
The court should also play a greater role in directing the course and conduct of the hearing itself. Although section 4244 does not specify the exact nature of the hearing, the hearing has often been described as an "adversary hearing," 171 presumably entailing the right to counsel, the right to present witnesses, and the right to cross-examination. But to view the hearing on competency as strictly adversarial in nature creates numerous problems and may actually defeat the purpose of the hearing.

In the first place, the label "adversary" is somewhat misleading to the extent that it implies that there are established "defense" and "prosecution" positions. It cannot be said that the prosecution as a rule wishes the defendant to be found competent, or that the defense will urge incompetency. The position taken by a party will depend largely on his assessment of his interests in the future of the criminal proceedings. This assessment is based on certain factors that vary from case to case, such as the possible severity of sentence, the strength of the opponent's case, and the advantages to be gained through delaying the proceedings. Thus, if the defendant faces relatively minor charges, the prosecutor may take the position that involuntary hospitalization is, if not preferable, at least equivalent to a criminal sentence on these charges. On the other hand, if the charges are serious, it may be to the defendant's advantage to be found incompetent in order to delay or possibly avoid conviction.

To be sure, one can generalize about the adversarial position likely to be taken by a party in any given situation. To the extent that courts rely on such generalizations, however, they risk skewing the competency inquiry. For example, certain notions about "burdens of proof" on the issue of competency have developed as a result of reliance on the view that the government has an interest

defendant's abilities on a scale from total incapacity to no incapacity in 13 different functions needed at trial. The 13 functions are: (1) appraisal of available legal defenses; (2) unmanageable behavior; (3) quality of relating to attorney; (4) planning of legal strategy, including guilty plea to lesser charges where pertinent; (5) appraisal of role of (a) defense counsel, (b) prosecuting attorney, (c) judge, (d) jury, (e) defendant, (f) witnesses; (6) understanding of court procedure; (7) appreciation of charges; (8) appreciation of range and nature of possible penalties; (9) appraisal of likely outcome; (10) capacity to disclose to attorney available pertinent facts surrounding the offense including the defendant's movements, timing, mental state, actions at the time of the offense; (11) capacity to realistically challenge prosecution witnesses; (12) capacity to testify relevantly; (13) self-defeating v. self-serving motivation (legal sense). It is fully understood by the proponents of this test that the various incapacities are not of equal importance and that, for example, a judge might very well conclude that the capacity to challenge witnesses is to be weighted less heavily than the capacity to testify. Massachusetrs STUDY, supra note 38 , at 98 .

in Stone v. United States, 358 F.2d 503 (9th Cir. 1966); Caster v. United States, 319 F.2d 850, 852 (5th Cir. 1963). 
in proving competency, at least where the charges are serious. In United States v. DiGilio ${ }^{172}$ the Third Circuit, noting that there is "surprisingly little case law" on the burden of proof question, ${ }^{173}$ held that the government has the burden of proving competency by a preponderance of the evidence. ${ }^{174}$ The court reasoned that it would be senseless to require the defendant to bear the burden of proving his own incompetency since the whole purpose behind examining competency is to determine if the defendant is able "to assume any burden in the adversarial judicial proceeding." 175

Leaving aside for the moment the question whether notions of "burdens" are reconcilable with the purpose of the competency hearing, the DiGilio decision demonstrates a lack of awareness of the practical problems faced by the prosecutor. Requiring the prosecutor to prove competency ignores the fact that the prosecutor is severely limited in his access to the type of evidence necessary to satisfy the burden of proof. Prior to the hearing, the government has no right to force the defendant to undergo a psychiatric exam conducted by the government's own experts. The prosecuting attorney may not even have access to the defendant so that he can form his own opinion about the defendant's present condition. Although the government will normally have a substantial file on the crime in question, this information will often be of little help at the competency hearing, particularly when there is indication that the defendant's mental status has altered or deteriorated since the crime occurred. Thus, other than the report of the court psychiatrist, the government at the commencement of the hearing has very little information with which to evaluate the defendant's competency, let alone prove it.

More important, the view espoused in DiGilio is at odds with the fundamental aspects of the law of incompetency to stand trial. Suppose that the government chose not to contest the finding of the court-appointed psychiatrist as to the defendant's incompetency. Would a court be justified in resolving the issue on the basis that there had been a failure of proof? Similarly, suppose that the defense attorney chose not to present any witnesses, not even the psychiatrist whose report prompted the hearing, and decided not to cross-examine government witnesses whose testimony supported

172538 F.2d 972 (3d Cir. 1976), cert. denied sub nom. Lupo v. United States, 429 U.S. 1038 (1977).

${ }^{173}$ Id. at 986.

ta Id. at 988. See also United States v. Shepard, 538 F.2d 107, 109 (6th Cir. 1976); United States v. Makris, 535 F.2d 899, 906-07 (5th Cir. 1976).

${ }_{175} 538$ F.2d 972, 987 (3d Cir. 1976), cert. denied sub nom. Lupo v. United States, 429 U.S. 1038 (1977). 
the competency of the defendant. Should this be decisive of the outcome?

I think the answer is no. In Pate $v$. Robinson, ${ }^{176}$ the Supreme Court scoffed at the notion that a defendant about whom there was a competency question could "waive" his incompetency. Robinson was represented by counsel, and the case implies that counsel could not waive or stipulate competency on behalf of his client. The same logic suggests that a court cannot resolve the competency issue simply on the basis of a failure of proof. Once the issue is raised, the court has the responsibility to determine it correctly. To the extent the parties have an adverse interest in the outcome, the court's task will be made easier. But ultimately, as the common law always recognized, the trial court must see to it that a thorough investigation of the issue is conducted.

For this reason the approach of the Third Circuit in DiGilio, which assumed an adversary hearing at which one side or the other must bear the burden of proof, is misconceived. The burden of determining competency belongs to the court and strategic decisions by the government or defense counsel should not be decisive in the outcome.

Section 4244 is consistent with this view of the court's responsibility. The statute permits the court to appoint its own psychiatrist so that, regardless of the evidence presented by the parties, the court can obtain expert testimony from a reliable source. If, after reviewing all of the evidence presented, the court is still undecided as to whether the defendant is competent, it should find the defendant incompetent rather than proceed to trial. The court's decision in close cases does not rest on the prosecutor's failure to establish his burden of showing that the defendant is competent, but on the trial court's responsibility to "jealously guard" the defendant's right to a fair trial. ${ }^{177}$ In those cases in which the court, on the basis of its independent inquiry, is convinced of the defendant's competency, trial should not be delayed simply because the prosecution may not have marshalled sufficient evidence that the defendant is competent.

\section{The Role of Defense Counsel}

The adversary view of the competency hearing also presents

176383 U.S. 375,384 (1966).

17 Drope v. Missouri, 420 U.S. 162, 173 (1975); Pate v. Robinson, 383 U.S. 375, 385 (1966). The Supreme Court in both cases described the respective competency statutes as "jealously guarding" the defendant's constitutional right to a fair trial. 
special problems for defense counsel. If the defense attorney's primary responsibility is to protect the defendant's exercise of his constitutional rights, what adversarial position should the attorney assume when the issue being determined is the ability of the defendant to exercise his rights? If the defendant has been offered a very advantageous plea, should the attorney argue vigorously for his client's competency, even though the attorney personally believes that the defendant is incompetent? Or in such a case should the attorney follow his own assessment of his client's competency and argue that the defendant is incompetent and that any plea would be involuntary?

If counsel's position at the hearing is limited by his personal assessment of the defendant's competency, then competency hearings are certainly distinct from other pretrial hearings. Counsel has no obligation to see that the court makes what counsel personally believes to be the correct ruling with respect to the suppression of evidence or the determination of probable cause. It could be argued similarly that the correct determination of competency is the responsibility of the court, not defense counsel and therefore, if he believes that a plea is in his client's best interest, counsel should take the adversarial position that his client is competent. The problem with this argument is that defense counsel has a responsibility for the correct determination of the competency issue that he does not have with respect to other issues. A trial court's erroneous rulings in favor of the defendant on issues other than competency do not adversely affect the defendant's constitutional rights; instead, the court may simply be giving those rights a broader sweep than it should. But if the court erroneously concludes that the defendant is competent, the court's decision goes directly to the defendant's ability to waive or assert his constitutional rights. Although it is the court's responsibility to determine the issue of competency, counsel has the obligation, flowing from his duty to protect his client's rights, to see that the issue is decided correctly. As with the question of raising the competency issue, counsel is not free to chart an adversary course at the hearing based on his view of the client's best interests.

Defense counsel's position at the hearing is further complicated by the fact that counsel's opinions and observations with respect to his client's competency may be quite probative. This stems from the nature of the competency issue, which in part involves the defendant's relationship with his attorney. At the outset of the hearing, counsel is in a far better position than the court and prosecutor to form an opinion about the defendant's competency. He will be aware of any problems in communication or cooperation that might 
hamper the presentation of the defense. ${ }^{178}$ In United States v. David, ${ }^{179}$ Judge Bazelon took note of defense counsel's special position, and urged trial courts to seek counsel's opinion. He pointed out that "counsel's first-hand evaluation of a defendant's ability to consult on his case and to understand the charges against him may be as valuable as an expert psychiatric opinion on his competency." 180 That counsel could be asked his personal opinion on the ultimate issue is certainly inconsistent with an adversary view of the hearing. As I have argued, however, counsel's obligation to protect the defendant's rights entails the duty to aid the court in making the correct competency decision and a court should be free to make such an inquiry of defense counsel.

A serious hurdle to examining the attorney as a witness is the attorney-client privilege. In a much earlier decision, Gunther $v$. United States, ${ }^{181}$ the D.C. Circuit concluded that such interrogation would violate the privilege. In Gunther the court remanded for a new competency hearing, with specific instructions that the former trial counsel not be called as a witness:

If trial counsel in a criminal case could be called by the Government and asked to give an opinion as to the accused's competency and ability to assist in the defense, he could necessarily also be asked for the factual data upon which he premised his opinion. These questions would open to inquiry by the Government the entire relationship between the accused and his counsel. Such revelations would be a violation of the attorney-client

178 The value of the lawyer's evaluation has been recognized by the Massachusetts Study, whose objective is to improve the accuracy of the competency determination. The Study concluded that a lawyer serving as a legal expert should be a part of the examination process. MASSACHUSETTS STUDY, supra note 38.

Dr. Louis McGarry, the principal investigator of the project, stated that in the course of previous work on competency, members of the Law-Medicine Institute of Boston University, the original grantee of the project, had become convinced

that an attorney-consultant was a necessary participant in the accurate appraisal of competency for trial. Although expertness with respect to the psychopathology on which a finding of incompetency to stand trial may be based is properly that of the psychiatrist and psychologist, the degree to which the disability impairs an individual's capacity to protect himself in the particular circumstances of his case often requires legal expertise.

McGarry, supra note 144 , at 53.

1" 511 F.2d 355 (D.C. Cir. 1975).

1No Id. at 360 . Other courts have emphasized the probative value of the defense counsel's opinion. See United States ex rel. Roth v. Zelker, 455 F.2d 1105, 1108 (2d Cir.), cert. denied, 408 U.S. 927 (1972). There is some confusion over the weight to be given counsel's opinion. See note 193 infra.

181 230 F.2d 222 (D.C. Cir. 1956). 
privilege and would also invade an accused's right to counsel in the trial of the criminal charge. ${ }^{182}$

That view was rejected by the Fourth Circuit in United States v. Kendrick, ${ }^{183}$ where the defendant claimed, in a collateral attack, that he had been incompetent at the time of trial. The Kendrick court concluded that it was permissible for the defendant's former trial counsel to testify at such a hearing because the attorney-client privilege is intended to protect only the substance of communications made by a client to his attorney in confidence, and not matters such as physical characteristics and demeanor, which "are not intended to be held in the breast of the lawyer, even though the attorney-client relation provided the occasion for the lawyer's observation of them." ${ }^{184}$ The Kendrick rationale is not entirely satisfactory. If the attorney's opinion is sought because he is in the best position to judge the difficulty that his client's mental disabilities presented in formulating a defense, the conclusion seems inescapable that some of the lawyer's opinions will be based on conversations that may fall within the scope of the attorney-client privilege. It may not be quite as simple as the court suggests for the attorney to distinguish between those observations that fall outside the privilege and those observations that are based on privileged confidences.

There is, however, stronger reason for holding that the interrogation of the attorney does not violate the attorney-client privilege. A defendant who attacks his conviction by claiming that he was not competent prior to the trial is implicitly charging that his trial attorney was ineffective in protecting his rights. When it is alleged that counsel's services were inadequate, the attorney should be allowed to defend his conduct. In addition, it seems inconsistent with the privilege to permit a defendant to affirmatively allege through affidavit and testimony that he was unable to understand the proceedings and consult with counsel, while at the same time offering the privilege as a bar to counsel's testimony on the matter. The privilege, in Wigmore's words, "is intended only as an incidental means of defense, and not as an independent means of attack, and to use it in the latter character is to abandon it in the former."18.5

${ }_{1 \times 2}$ Id. at $223-24$.

183 331 F.2d 110 (4th Cir. 1964).

Iss Id. at 113-14. Other circuits have accepted Kendrick and rejected Gunther. See, e.g., Clanton v. United States, 488 F.2d 1069 (5th Cir. 1974); Howell v. United States, 442 F.2d 265 (7th Cir. 1971).

iss 8 J. WIGMORE, EvidENCE $\$ 2327$, at 638 (McNaughton Rev. 1961). 
The Fifth Circuit, in United States $v$. Woodall, ${ }^{186}$ faced the issue in an analogous situation. In Woodall, the defendant attacked his guilty plea on the ground that at the time he entered the plea he was unaware of the maximum penalty that could be imposed. At the hearing to determine if Woodall was aware of the maximum penalty, Woodall's former attorney testified that he had advised Woodall of the maximum penalty. The court en banc held that the attorney's testimony did not violate the attorney-client privilege because Woodall's attack on his plea, with its implied charge of attorney negligence, amounted to a waiver of the privilege. ${ }^{187}$ The court's conclusion was based on the belief that the assertion of the privilege should not be used affirmatively to subvert or conceal the truth. The court said that it could not justify a rule permitting a defendant to assert that he was misinformed, and "then permit him to run a procedural trap play that would block the development of the plain truth ....."188

Questioning defense counsel at a pretrial competency hearing presents a somewhat different problem from that involved in a collateral attack alleging prior incompetency. The defendant may not have raised the competency issue; even if he did, it makes little sense to view the motion as a waiver if the issue is whether the defendant is presently competent to waive his rights. On the other hand, it seems very disturbing that a court should have to determine whether there are presently significant problems between the defendant and his attorney without the ability to seek out the evidence that might be most probative in determining whether the problems stem from the client or from the lawyer. The problem seems analo-

1 so 438 F.2d 1317 (5th Cir. 1970).

${ }_{187} 7$ The Fifth Circuit did not reach its conclusion easily. Originally a panel concluded that the testimony of the defendant's former attorney was improperly admitted because it was privileged. $438 \mathrm{~F} .2 \mathrm{~d}$ at 1319-20. On petition for rehearing the government argued that Woodall by his attack on his plea was making an implied attack on the effectiveness of counsel. The petition was denied with a second opinion in which the panel stated it was reluctant to "begin eroding a rule of ancient origin." $438 \mathrm{~F} .2 \mathrm{~d}$ at 1321-22. A petition for rehearing en banc was granted and the Fifth Circuit held that the privilege had been waived. 438 F.2d at 1324-26.

19 Id. at 1326. The District Court for the District of Columbia had earlier applied the same rationale to permit counsel to testify in a collateral attack alleging prior incompetency. United States v. Wiggins, 184 F. Supp. 673 (D.D.C. 1960). The court avoided Gunther by reading Gunther to bar only opinions by counsel on competency and not "detailed observations" by counsel. Id. at 673 .

The proposed federal rule of evidence on the attorney-client privilege, which was not enacted, included an exception for " $a$ communication relevant to an issue of breach of duty by the lawyer to his client . . . " Proposed Federal Rule of Evidence 503(d)(3), 56 F.R.D. 236 (1972). The Advisory Committee Notes state that this exception is required by considerations of "fairness and policy" when questions arise including claims of inadequacy of representation. Id. at 240 . 
gous to a defense attorney's motion to withdraw based on friction in the relationship, where courts feel an obligation to inquire into the nature of the problems even if such problems touch on matters of trial strategy usually thought to be within the scope of the privilege. ${ }^{189}$

The attorney-client privilege should not bar the court's inquiry into the relationship between the attorney and the client. When the defendant may not even understand the role of counsel, it seems artificial to suggest that the privilege blocks inquiry into the relationship. The court's questioning of defendant's attorney is in part an inquiry into whether the attorney-client privilege exists. Moreover, the result of finding the attorney-client privilege applicable would be to trap the defendant in a privilege he is unable to waive at the hearing. It seems that given the nature of the competency issue and the importance of an accurate determination to the defendant's exercise of his rights, a court should view a full inquiry into the relationship between the defendant and the attorney, including questioning of defense counsel, as part of its responsibility. ${ }^{190}$ Any information obtained at the hearing should not, of course, be used against the defendant at trial.

If the court is permitted and even encouraged to seek the opinion of counsel on the ultimate issue of the defendant's ability to understand the proceedings and present an effective defense, attorneys will be deterred from using competency as a strategic move to avoid or delay a certain conviction, for counsel cannot be both a witness and an advocate at the same time. Counsel could hardly testify to his client's 'competency and yet argue vigorously in favor of incompetency. ${ }^{191}$ This consequence may be upsetting to defense

${ }^{189}$ See, e.g., United States v. Main, 443 F.2d 900 (9th Cir. 1971); Jackson v. United States, 412 F.2d 149 (D.C. Cir. 1969). See also United States v. McMann, 386 F.2d 611 (2d Cir. 1967) (setting out standard for ruling on withdrawal that requires court to balance "prejudice to the legitimate interests of the defendant" against "potential disruption of the proceedings"). These cases do not discuss, or even recognize any attorney-client privilege difficulties, but they indicate that courts have no hesitancy in examining difficulties in the relationship.

${ }^{100}$ It is important that a court view competency as involving a relationship between the lawyer and his client and not just as a quality of the defendant. The Massachusetts Study found that the interpersonal skills of the particular defense attorney and his sustained involvement in working with a defendant could make a difference in whether the defendant was competent. The Study concluded: "A skillful, supportive attorney who devotes adequate time to working with mentally ill defendants can maximally facilitate the coping strengths of such defendants. The converse is equally true." MassachusetTs Study, supra note 38, at 7.

'1' The Disciplinary Rules of the Code of Professional Responsibility call for withdrawal either when a lawyer becomès "a witness on behalf of his client" or when not a witness on behalf of his client, it is apparent that this testimony "is or may be prejudicial" to this client. ABA Code of Professional ResponsibiLITy DR 5-102 (1976). Logically, this rule should not 
lawyers who tend to view incompetency and insanity as "two prongs of a general insanity defense."182 But competency should not be viewed as a defense, and the role of counsel in raising and presenting an insanity defense or any other defense is fundamentally different from his role when a question arises concerning defendant's ability to stand trial. ${ }^{193}$

Of course, counsel's testimony at the hearing may in certain cases seriously strain the relationship with his client. Such strain may occur whenever the client views the attorney's testimony as unfavorable to the determination that the client views as desirable. But if counsel is obligated to raise the issue, a certain amount of friction seems inevitable, regardless of whether the attorney testifies. A court confronted with a serious competency question should be sensitive to such problems and should be ready to appoint new counsel whenever it becomes apparent that a strain in the relationship may hamper the defense. ${ }^{194}$

I have tried to suggest that when the question raised involves the ability of the defendant to function with counsel in an adversary setting, the answer cannot be expected to flow from an adversary hearing. In view of the problems posed for both the prosecutor and the defense counsel when faced with a question of competency, they cannot be expected to fulfill their paradigmatic adversarial roles. This is not meant to deemphasize the importance of the procedural protections afforded by an adversarial hearing. It is, however, meant

be applied in the context of a competency hearing because of the nonadversarial nature of the hearing, unless it is clear that the attorney-client relationship is so strained as to impair their ability to work together.

"12 Foote, supra note 51 , at 834.

is To the extent that there is confusion over the role of counsel at the hearing, it is difficult for a court to know how to evaluate statements by counsel at the hearing. In McKinney v. State, 566 P.2d 653, 660 (Alaska 1977), the Alaska Supreme Court indicated that although defense counsel's assessment of competency "should be accorded substantial weight," this only applied if defense counsel offered the opinion that his client was competent. The court stated that the same weight need not be given counsel's assertion that the client is incompetent because "an attorney's duty as an advocate will often require him to present those arguments on behalf of his client, and while his opinion is still relevant, it is not determinative." Id. The implication seems to be that if counsel offers or is called on for his personal assessment of his client's competence his duty as an advocate may require him to give an opinion that is not his honest opinion but is his "advocate's opinion" and can therefore be ignored.

Until courts and lawyers are clear on the role of defense counsel at the hearing and the nature of the hearing, there is always going to be confusion over the weight to be attached to counsel's remarks. There should be no need for "rules" to guide trial courts in assessing evidence. Certainly the suggestion of the Alaska Supreme Court that the nature of the opinion indicates when counsel is acting as an advocate is questionable advice. See text preceding note 178 supra.

is See note 191 supra. 
to suggest that the trial court must play a far greater role in directing the course of the competency hearing than it plays in conducting other kinds of hearings. Rather than rely on adversarial procedures of cross-examination and burdens of proof, the court in a competency hearing should control the course of the hearing, both in calling witnesses and in questioning witnesses. Such control should not be viewed as discretionary-it is mandated by the court's ultimate responsibility for the proper determination of the competency issue.

\section{REFORM}

I have argued in this article that competency proceedings in federal courts are frequently misunderstood and misused. To a large extent, these problems arise from a failure to consider in detail the full implications of the competency issue. Although section 4244 was an important step in forcing courts to recognize the problem of competency, it fails to deal with some of the major aspects of the problem. As a result, the courts have had to face such problems in a piecemeal fashion - an approach that is no doubt responsible for some of the present confusion in the area. A new statute on competency is now pending in Congress as part of the general reform of the Criminal Code Reform Act of 1977. Although the proposed statute, embodied in S. 1437, is for the most part modeled after section $4244,{ }^{195}$ it does propose several significant changes.

Section 3611 of the new code would make two major improvements in the rules governing competency. The first of these improvements is the establishment of a specific upper limit on the length of time that a defendant who is found incompetent may be institutionalized pending his recovery. A defendant found to be incompetent can be hospitalized for at most four months in order to determine whether there is a substantial probability that the defendant will regain competency. If, after the initial four months, there appears to be a substantial probability of recovery, he can be hospitalized for at most an additional two months. ${ }^{196}$ The result is that a

193 The bill, S. 1437, which is entitled the "Criminal Code Reform Act of 1977" was introduced into the Senate on May 2, 1977, by Senators Edward Kennedy and John McClellan. S. 1437, 95th Cong., 1st Sess., 123 Covg. Rec. S6833-41 (daily ed. May 2, 1977). The Senate Committee on the Judiciary reported the bill, with revisions, on Nov. 15, 1977. The revised text of the bill is contained in S. REP. No. 95-605, 95th Cong., 1st Sess. (1977) [hereinafter cited as S. 1437].

106 Section 3611(d) provides that upon a finding by a preponderance of evidence that the defendant is incompetent,

the court shall commit the defendant to the custody of the Attorney General. The Attorney General shall hospitalize the defendant for treatment in a suitable facility: 
defendant found to be incompetent could be hospitalized for six months maximum. However the proposed statute specifically allows the government the option of civil commitment proceedings when a defendant is permanently incompetent. ${ }^{197}$

The second major improvement proposed by section 3611 is that a hearing would be required in every case in which competency is properly raised. ${ }^{198}$ To require a hearing whenever the issue is raised seems consistent with the emphasis placed on the hearing in Robinson and Drope. It would be a welcome contrast to section 4244, which requires a hearing only if the psychiatric report concludes that the defendant is incompetent. ${ }^{189}$ Unfortunately, the view persists that the hearing should be an adversary hearing. Subsection 3611 (c) incorporates the hearing procedures of section 3616(d), which provides that the defendant "shall be afforded an opportunity to testify, to present evidence, to subpoena witnesses on his behalf, and to confront and cross-examine witnesses who appear at the hearing. ${ }^{200}$ Moreover, the proposed statute apparently intends to reverse the present "burden of proof" to find "by a preponderance of the evidence that the defendant is presently suffering from a mental disease or defect rendering him mentally incompetent."202 Even the present law under section 4244

(1) for such a reasonable period of time, not to exceed four months, as is necessary to determine whether there is a substantial probability that in the foreseeable future he will attain the capacity to permit the trial to proceed; and

(2) for an additional reasonable period of time, not to exceed two months until:

(A) his mental condition is so improved that trial may proceed, if the court finds that there is a substantial probability that within such additional period of time he will attain the capacity to permit the trial to proceed; or

(B) the pending charges against him are disposed of according to law; whichever is earlier.

S. $1437 \S 3611$ (d), supra note 195 , at 262 .

in S. $1437 \S 3611$ (d), supra note 195 , at 262 . The proposed federal code contains a broadened civil commitment statute. See S. $1437 \S 3615$, supra note 195, at 267-70.

19x Section 3611 (a) reads as follows:

At any time after the commencement of a prosecution for an offense and prior to the sentencing of the defendant, the defendant or the attorney for the government may file a motion for a hearing to determine the mental competency of the defendant. The court shall grant the motion, or shall order such a hearing on its own motion, if there is reasonable cause to believe that the defendant may presently be suffering from a mental disease or defect rendering him mentally incompetent to the extent that he is unable to understand the nature and consequences of the proceedings against him or to assist in his defense.

S. $1437 \S 3611$ (a), supra note 195 , at 261.

i"' See text and note at note 160 supra.

200 S. $1437 \$ 3616$ (d), supra note 195, at 271.

201 See text and note at note 172 supra.

202 S. $1437 \S 3611$ (d), supra note 195, at 262. 
seems preferable to this change in burdens of proof. The new statute misconceives the responsibility of the trial court. It will permit the court to try a defendant even if the court, after having heard the evidence, remains uncertain as to the defendant's competency.

As I have suggested, the concept of an adversarial competency hearing creates numerous problems and obscures the major purpose behind competency inquiries. Any reform of section 4244 should begin by squarely placing the responsibility for the proper determination of competency where it belongs - on the trial court. Thus, I would propose the following reform:

Whenever the issue of competency is raised, the trial court shall conduct and control a thorough hearing into the competency of the defendant. The court shall hear testimony from the defendant and the examining psychiatrist(s) in order to assure itself of the competency of the defendant.

By placing the burden on the court to conduct and control the inquiry into the defendant's competency, this proposal accords with the traditional view that the trial court bears the responsibility to correctly determine the competency question. The second sentence of the proposal recognizes that the issue of competency is simply too important to permit the court to resolve the issue without hearing from both the defendant and the psychiatrist, or psychiatrists, who examined the defendant. If the waiver of constitutional rights in a guilty plea demands the "utmost solicitude of which events are capable in canvassing the matter with the accused," 203 this same solicitude should be shown in determining the defendant's ability to understand the proceedings when there is reason to believe that he may be incompetent.

The proposed statute makes a number of changes with regard to raising the issue of competency. First, it squarely obligates the trial court to order a hearing sua sponte if there is "reasonable cause to believe" that the defendant may be incompetent. ${ }^{204}$ This has always been viewed as the trial court's obligation. ${ }^{205}$ However, while section 4244 placed the same obligation on the government attorney, the proposed statute indicates only that "the attorney for the government may file a motion for a hearing to determine the mental competency of the defendant." ${ }^{206}$ This change may be constitution-

${ }^{203}$ Boykin v. Alabama, 395 U.S. 238, 243-44 (1969).

${ }^{204}$ S. 1437 \$ 3611 (a), supra note 195 , at 261 .

${ }^{205}$ See text and notes at notes 25-31 supra.

${ }^{206}$ S. $1437 \$ 3611(a)$, supra note 195 , at 261 . 
ally infirm if it is meant to relieve the prosecutor of his obligation to raise the issue. Due process would seem to require a prosecutor to reveal to the court any evidence suggesting that the defendant may be incompetent. ${ }^{207}$

With regard to defense counsel, section 3611 provides only that, like the government, "the defendant . . . may file a motion." 208 This change does nothing to dispel the uncertainty that exists over defense counsel's obligation to raise incompetency. I have argued that counsel should have no choice but to raise the issue of competency. However, the position I have put forward runs counter to the instincts of many attorneys; indeed, even those who have recognized the issues involved have expressed uncertainty over the course of action counsel should take when faced with a competency problem. ${ }^{209}$ Unfortunately, section 3611 provides no more guidance than does section 4244 . In place of the reform proposed by section 3611 , I would suggest adoption of the following principle:

It shall be the obligation of the government attorney and the defense attorney to file a motion for judicial determination of the accused's competency whenever either of them has reason to believe the defendant may be incompetent. Whenever the court has reason to believe the defendant may be incompetent, it shall, on its own motion, cause the accused to be examined as to his mental condition.

Except with regard to the role of the defense attorney, this proposal would be a fair statement of the present law. It not only incorporates the government attorney's obligation to raise competency under section 4244 , but also reflects present caselaw with regard to the court's obligation to raise the competency issue. ${ }^{210}$ Finally, this proposal clearly spells out the obligation of the defense attorney who previously had no guidance in this regard.

Section 3611 makes no changes in the protections afforded the defendant either at the time of the examination or at the hearing. Although section 3612 does provide for a psychiatric examination upon government motion into sanity at the time of the offense, ${ }^{211}$ the Judiciary Committee Report specifically notes that this statute is not meant to limit the inherent judicial power to order an examina-

\footnotetext{
207 See text and notes at notes 66-73 supra.

S. $1437 \$ 3611$ (a), supra note 195 , at 261.

201 See Chernoff \& Scharfer, supra note 60, at 519.

21. See text and notes at notes 25-31 supra.

211 S. $1437 \S 3612(a)$, supra note 195, at 263.
} 
tion into sanity. ${ }^{212}$ Thus, section 3611 , like section 4244 , will no doubt be viewed as consistent with the court's power to order dual purpose examinations.

The practice of ordering defendants to submit to dual purpose examinations raises serious constitutional questions. It forces a defendant to submit to an unnecessarily intensive and probing examination without requiring any showing of need on the part of the government and impinges on values underlying the privilege against self-incrimination. It encourages prosecutors to misuse competency, by turning the issue into a vehicle for early government discovery on sanity even though rule 12.2 implies that such discovery should be available only upon notice of an intent to raise the insanity defense. ${ }^{213}$ The use of the competency examination as a vehicle for discovery is plainly inconsistent with the nonadversarial theory of the competency inquiry. A proposal should be adopted to provide:

Any court-ordered examination as to the accused's competency to stand trial must be strictly limited to the issue of competency. The examining psychiatrist(s) may not, on the basis of this examination, testify on the issue of the defendant's mental condition or sanity at the time of the offense.

Not only does section 3611 permit dual purpose examinations, it also contains a change that may further confuse the issues of competency and insanity. One objective of the draftsmen was to incorporate into the statute the standard by which competency is to be determined. The proposed statute frames the issue in terms of whether

the defendant may be presently suffering from a mental disease or defect rendering him mentally incompetent to the extent that he is unable to understand the nature and consequences of the proceedings against him or to assist in his defense. ${ }^{214}$

By injecting the criterion of a "mental disease or defect" responsible

${ }^{212}$ Criminal Code Reform Act of 1977, Report of the Committee on the Judiciary of the United States Senate, S. Rep. No. 95-605, 95th Cong., 2d Sess. 1035 (1977).

${ }^{213}$ The timing of an examination into sanity can be very important. If there is a significant difference in the dates on which conflicting experts examined the defendant, the earlier examination may carry more weight with a jury because it is closer to the date of the crime. See Hughes v. United States, 306 F.2d 287, 289 (D.C. Cir. 1962). If the government is forced to wait until the defense gives appropriate notice under rule 12.2, the defense psychiatrists will have examined the defendant first. By raising competency and obtaining a dual purpose examination, the timing problem may work to the advantage of the government.

214 S. 1437 \& 3611(a), supra note 195, at 261. 
for the defendant's incompetency, the statute adds, at best, a guaranteed source of confusion and, at worst, a potentially mischievous new element. In Dusky v. United States, the Supreme Court stated that the "test must be whether [the defendant] has sufficient present ability to consult with his lawyer with a reasonable degree of rational understanding - and whether he has a rational as well as a factual understanding of the proceedings against him." 215 No mention is made of "mental disease or defect"; the test is framed in purely functional terms. ${ }^{216}$ Use of the terms "mental disease or defect" in the proposed statute invites confusion and may lead to the same kind of problems that have plagued the administration of the insanity defense.

There is an additional problem with regard to the defendant's testimony at the hearing that is not adequately addressed by either section 4244 or the proposed statute. Section 4244 prohibits the use at trial of a defendant's statements to his psychiatrist. But there is nothing in section 4244 that prohibits the use at trial of defendant's statements at the competency hearing. Surely a defendant cannot, consistently with the fifth amendment, be required to testify at the hearing at the price of incriminating himself. ${ }^{217}$

The protection afforded the defendant's statements under section 3611 would be identical to that in section $4244^{218}$ and would be just as inadequate. Under section 3611, the defendant's statements to the psychiatrist are not "admissible as evidence against the accused on the issue of guilt." ${ }^{219}$ No protection is given the defendant's

215362 U.S. at 402.

210 It appears that the injection of the phrase "mental disease or defect" into the competency standard started with the American Law Institute's Model Penal Code which used the phrase in its standard for competency. See Model Penal CODE \$ 4.04 (1962). But the draft of $\$ 4.04$ was completed in 1955 , several years prior to the decision in Dusky v. United States, 362 U.S. 402 (1960). See Model Penal Code (Tent. Draft No. 4, 1955).

217 In Simmons v. United States, 390 U.S. 377 (1968), the Supreme Court held that testimony by a defendant in order to establish standing to assert his fourth amendment rights could not be used against the defendant at trial. The competency situation is far stronger because (1) the court needs such testimony to make its determination; (2) the issue at stake goes right to the voluntariness of the defendant's testimony; and (3) the defendant may not have even raised the issue. The defendant should be protected not only against substantive use of such statements but their use as a source of leads or for purposes of impeachment. See Blaisdell v. Commonwealth, Mass. 364 N.E.2d 191, 199 (1977).

21: Section $3616(\mathrm{~g})$ of the proposed statute provides that any "statement made by the defendant during the course of a psychiatric examination pursuant to section 3611 or 3612 is not admissible as evidence against the accused on the issue of guilt in any criminal proceeding." S. $1437 \S 3616(\mathrm{~g})$, supra note 195 , at 272 .

210 If anything, it is clearer that the protection of $\$ 3616$ given to the defendant's statements, see note 218 supra, is not meant to bar a psychiatrist from testifying against the defendant in rebuttal of an insanity defense, since $\$ 3616$ applies to examinations into sanity under $\$ 3612$ which are expressly for the purpose of rebutting such a defense. 
statements at the hearing. To alleviate this problem, the statute should provide:

No statements made by the defendant in the course of the examination or at the hearing shall be admissible against the defendant at trial.

There is one other minor change ${ }^{220}$ in the proposed statute regarding the psychiatric examination and the determination of competency. Under the proposed statute a psychiatric examination would no longer be mandatory upon a showing of reasonable cause, ${ }^{221}$ although the Senate Judiciary Committee Report suggests that it would be an abuse of discretion for a court to refuse to order an examination "where the facts warrant an examination." 222 It is not clear why an examination is not warranted whenever there is reasonable cause to believe the defendant might be incompetent.

Although the proposed statute would effect some welcome reforms, the more serious problems that have arisen under section 4244 have not been addressed. Extensive overhaul of the competency provisions is badly needed.

\section{Conclusion}

Despite its long history, the issue of competency to stand trial has never received the attention that scholars have lavished on the insanity defense. As a result, we seem to have lost perspective on the issue, leading to serious confusion in the federal courts. Indeed, several years ago the prohibition against the trial of an incompetent defendant was attacked as a piece of "common law theology," largely outmoded in these days when counsel can carry on the battle even if the defendant cannot. ${ }^{223}$

While arguing that procedures for determining competency are

${ }^{220}$ It should be noted that S. 1437, as it stood before the most recent revision by the Senate Judiciary Committee, would also have required the appointment of two court-selected psychiatrists for any examination into competency. S. $1437 \S 3617$ (b)(1), 95th Cong., 1st Sess., 123 Cong. REc. S6833-41 (daily ed. May 2, 1977). This would have been a welcome departure from $\$ 4244$ 's heavy reliance on the "neutral expertise" of a single psychiatrist.

However, the Senate Judiciary Committee reconsidered the question and revised what is now $\$ 3616(\mathrm{~b})(1)$ to eliminate the two-psychiatrist requirement. S. $1437 \S 3616(\mathrm{~b})(1)$, supra note 195 , at 270 . This seems unfortunate because, as a Senate Judiciary Report had earlier noted, there was a "significant variation of expert judgment" on the competency issue. Criminal Justice Codification, Revision and Reform Act of 1974, Report of the Committee on the Judiciafy of the United States Senate, 93d Cong., 2d Sess. 1003 (1975).

221 S. $1437 \S 3611$ (b), supra note 195, at 261.

222 See Criminal Code Reform Act of 1974, supra note 212, at 1030.

23 Burt \& Morris, supra note 51, at 75-76. 
confused to the point of raising serious constitutional problems, I have also attempted to show that this "common law theology" had its origins in a belief that the defendant must be able to play a meaningful role in his trial - a belief that Faretta suggests is still very much alive. A corollary of this imperative is that the role of counsel in a criminal defense is, in the final analysis, the role of an assistant only. Until this limited role of counsel is understood, serious problems concerning counsel's obligation to raise competency, the nature of the hearing, and the role of the court will continue to plague the issue of competency. 